\title{
Modelling weathering processes at the catchment scale: The WITCH numerical model
}

\author{
Yves Goddéris ${ }^{\mathrm{a}, *}$, Louis M. François ${ }^{\mathrm{b}}$, Anne Probst ${ }^{\mathrm{a}}$, Jacques Schott ${ }^{\mathrm{a}}$, \\ David Moncoulon ${ }^{a}$, David Labat ${ }^{a}$, Daniel Viville ${ }^{\mathrm{c}}$ \\ a Laboratoire des Mécanismes et Transferts en Géologie, Observatoire Midi-Pyrénées, CNRS, Toulouse, France \\ ${ }^{\mathrm{b}}$ Laboratoire de Physique Atmosphérique et Planétaire, Université de Liège, Belgium \\ c Centre de Géochimie de la Surface, Strasbourg, France
}

Received 8 April 2005; accepted in revised form 4 November 2005

\begin{abstract}
A numerical model of chemical weathering in soil horizons and underlying bedrock (WITCH) has been coupled to a numerical model of water and carbon cycles in forest ecosystems (ASPECTS) to simulate the concentration of major species within the soil horizons and the stream of the Strengbach granitic watershed, located in the Vosges Mountains (France). For the first time, simulations of solute concentrations in soil layers and in the catchment river have been performed on a seasonal basis. The model is able to reproduce the concentrations of most major species within the soil horizons, as well as catching the first-order seasonal fluctuations of aqueous calcium, magnesium and silica concentrations. However, the WITCH model underestimates concentrations of $\mathrm{Mg}^{2+}$ and silica at the spring of the catchment stream, and significantly underestimates $\mathrm{Ca}^{2+}$ concentration. The deficit in calculated calcium can be compensated for by dissolution of trace apatite disseminated in the bedrock. However, the resulting increased $\mathrm{Ca}^{2+}$ release yields important smectite precipitation in the deepest model layer (in contact with the bedrock) and subsequent removal of large amount of silica and magnesium from solution. In contrast, the model accurately accounts for the concentrations of major species $(\mathrm{Ca}, \mathrm{Mg}$ and silica) measured in the catchment stream when precipitation of clay minerals is not allowed. The model underestimation of $\mathrm{Mg}^{2+}$ and $\mathrm{H}_{4} \mathrm{SiO}_{4}$ concentrations when precipitation of well crystallized smectites is allowed strongly suggests that precipitation of well crystallized clay minerals is overestimated and that more soluble poorly crystallized and amorphous materials may be forming. In agreement with observations on other watersheds draining granitic rocks, this study indicates that highly soluble trace calcic phases control the aqueous calcium budget in the Strengbach watershed.
\end{abstract}

(C) 2005 Elsevier Inc. All rights reserved.

\section{Introduction}

Since the early work by Walker et al. (1981), continental silicate weathering has been recognized as a major controlling factor of the geological carbon cycle, and hence of climate (Goddéris and François, 1995; Kump and Arthur, 1997; Kump et al., 2000; Berner and Kothavala, 2001; Donnadieu et al., 2004; Goddéris and Joachimski, 2004). Even at shorter timescales, there is a growing interest in fluctuations of large scale consumption of atmospheric

\footnotetext{
* Corresponding author.

E-mail address: godderis@lmtg.obs-mip.fr (Y. Goddéris).
}

$\mathrm{CO}_{2}$ during the recent glacial-interglacial cycles (Munhoven, 2002), as well as in the present-day global warming induced by human activities. For instance, the GEM-CO $\mathrm{CO}_{2}$ model, which calculates the weathering rates with a $1^{\circ}$ latitude $\times 1^{\circ}$ longitude on the basis of simple parametric laws linking large scale runoff to rock weathering (Amiotte-Suchet et al., 2003), has been coupled to a 3D model of carbon transport within the ocean to evaluate the impact of the continental alkalinity input on the presentday inter-hemispheric $\mathrm{CO}_{2}$ signal (Aumont et al., 2001).

Nevertheless, recent extensive field studies performed on small and large scale watersheds have shown that the behaviour of large scale (large scale in the sense of 
watershed scale) silicate weathering is more complex than the rather simple runoff (and possibly temperature) dependence used until now (most of them rely on the Brady and Carroll (1994) and White and Blum (1995) studies). Although standard temperature-runoff parametric laws generally apply to basaltic lithologies (Dessert et al., 2001, 2003), the relationship between temperature, runoff and $\mathrm{CO}_{2}$ consumption for granitic lithologies is much more variable and complex (Oliva et al., 2003). Moreover, it has been shown that trace minerals may play a fundamental role in base cations release and atmospheric $\mathrm{CO}_{2}$ consumption by granitic lithologies. For instance, Oliva et al. (2004) have shown that trace minerals (mainly trace calcic phases) account for $80-90 \%$ of the calcium flux exported from a high mountain watershed. Blum et al. (2002) reported that about $35 \%$ of the $\mathrm{Ca}$ exported from the Hubbard Brook catchment likely came from trace apatite dissolution.

A main challenge for the accurate description of continental weathering is to identify the main factors controlling chemical weathering and to quantify their effect in given environments and at various geometric and time scales. A critical step to rise to this challenge is the building of a numerical model describing the large-scale (watershedscale) weathering of silicate rocks, based on a description of the weathering processes as mechanistic as possible (including dissolution of primary and secondary minerals and precipitation of secondary minerals, in interaction with continental vegetation and coupled to hydrological processes). Mechanistic models already exist that work at the square-meter-scale in natural environments and are capable of describing weathering processes down to approximately the root depth. For instance, kinetic models such as the KINDIS code (Madé et al., 1994) have been used in an attempt at describing mineral dissolution in natural environment (Probst et al., 2000). Among those models, the pioneering and most complete one is surely the SAFE model developed by Sverdrup and Warfinge (1995) that has been tested and validated for many locations and has been upscaled in several countries to create regional weathering maps. This model, however, has been essentially used to describe critical loads and soil acidification in natural ecosystems and not within the scope of predicting the geochemical cycling of elements, including carbon, during weathering. Furthermore, it may be not appropriate to estimate weathering in deep soil profiles since it does not explicitly incorporate the calculation of chemical affinities and secondary mineral precipitation which may be critical, particularly below the root zone where solutions become supersaturated with respect to both primary and secondary minerals. It should be noted that recent developments of the SAFE model lead to the building up of an integrated model of soil and vegetation processes in forest ecosystems (ForSAFE) working at the centennial timescale (Wallman et al., 2005, 2002), designed for sustainability assessments.

We propose here a first step towards the establishment of a mechanistic numerical model of silicate weathering operating at the catchment scale, through the numerical coupling of a new weathering model (WITCH) and a model of water and carbon cycles in forest ecosystems (ASPECTS, Rasse et al. (2001)). It must be kept in mind that given the variety of processes that must be accounted for, this study presents only a first effort towards this goal. The originality of our approach lies in the direct comparison of the results of this model on a seasonal timescale with the data acquired on a monolithological granitic catchment located in the Vosges Mountains in France (the Strengbach watershed). This watershed represents an ideal site for an upscaling study since hydrological and geochemical data are available for several soil profiles (from October 1994 to October 1995 with a 15 day timestep), for a spring collector (catching the four main springs of the main stream) and for the main stream itself (from 1985 to 1998 with a weekly timestep). Furthermore, the 1994-1995 year can be considered as a typical period on an hydrological point of view, since the total rainfall $(1397 \mathrm{~mm})$ is very close to the mean rainfall calculated over 13 years of data acquisition $(1320 \mathrm{~mm})$. Soil solutions sampled at different depths will be used to validate the geochemical sub-model (including kinetic mineral dissolution and precipitation), while data from spring collectors can be used as a validation of the upscaling procedure. Finally, it should be kept in mind that this catchment was also intensively studied because of large pollutant input through atmospheric deposition. Such input strongly perturbates the natural system and should thus be incorporated in the model. Modelling this perturbation is probably a challenge for the future, but it is already partly considered within this preliminary work since seasonal fluctuations in atmospheric acidic deposition are accounted for.

\section{Model description}

\subsection{The WITCH model}

The WITCH geochemical model is a box model that integrates the chemical composition of $n$ boxes representing the soil solution as a function of time ( $n$ can be defined depending on the field configuration). The mass balance is calculated for each box at each timestep:

$\frac{\mathrm{d} C}{\mathrm{~d} t}=F_{\text {top }}-F_{\text {bottom }}+F_{\text {weath }}+F_{\text {exchange }}-F_{\text {prec }}$,

where $C$ is the box content for a given species $\left(\mathrm{Ca}^{2+}, \mathrm{Mg}^{2+}\right.$, $\mathrm{K}^{+}, \mathrm{Na}^{+}, \Sigma \mathrm{SiO}_{2}(\mathrm{aq}), \Sigma \mathrm{Al}, \mathrm{SO}_{4}{ }^{2-}, \Sigma \mathrm{PO}_{4}$ and acid neutralizing capacity). $\mathrm{NH}_{4}{ }^{+}$and $\mathrm{NO}_{3}{ }^{-}$are not explicitly modelled, and are simply accounted as proton suppliers. $F_{\text {top }}$ represents the input flux at the top of the considered box through drainage while $F_{\text {bottom }}$ is the output flow at the base of the box. $F_{\text {weath }}$ represents the input of elements from dissolution of primary and secondary minerals. $F_{\text {exchange }}$ could be either positive or negative, and accounts for cation exchange between the soil solution and the clay-humic exchange complex, and $F_{\text {prec }}$ represents the removal of elements through the precipitation of secondary 
minerals. Three additional differential equations are written to calculate the fraction of sites on the exchange complex occupied by, respectively, $\mathrm{Ca}^{2+}, \mathrm{Mg}^{2+}$ and $\mathrm{K}^{+}$. We did not include any exchange of $\mathrm{Na}^{+}$. The exchange processes are described assuming a Fick diffusion law (Sverdrup and Warfinge, 1995), and are thus described in a fully dynamic way:

$\frac{\mathrm{d} E_{\mathrm{BC}}}{\mathrm{d} t}=-k_{x} \cdot\left(\mathrm{BC}_{\text {surf }}-\mathrm{BC}_{\mathrm{sol}}\right)$,

where $E_{\mathrm{BC}}$ is the fraction of sites occupied by a given base cation $\mathrm{BC}\left(\mathrm{Ca}^{2+}, \mathrm{Mg}^{2+}\right.$ or $\left.\mathrm{K}^{+}\right), \mathrm{BC}_{\mathrm{sol}}$ is the concentration of the base cation in the soil solution calculated at time $t$, and $\mathrm{BC}_{\text {surf }}$ is the concentration of $\mathrm{BC}$ at the exchange surface. $\mathrm{BC}_{\text {surf }}$ are calculated as a function of the $\mathrm{H}^{+}$concentration at the surface, itself estimated from the acid neutralizing capacity (ANC) change between the solution and the exchange complex during the exchange process (Alveteg, 1998). The cation exchange capacity (CEC) is held constant within each soil layer. Finally, $k_{x}$ is a mass transfer coefficient (Warfinge and Sverdrup, 1998).

Dissolution of primary and secondary minerals is described through kinetic laws derived from transition theory concept (Eyring, 1935). Overall dissolution rates $R_{\mathrm{S}}$ are assumed to be the sum of $\mathrm{H}^{+}, \mathrm{OH}^{-}, \mathrm{H}_{2} \mathrm{O}$ and organic ligands promoted dissolution:

$R_{\mathrm{S}}=A \cdot\left[\sum_{\mathrm{i}} k_{i} \exp \left(\frac{-E_{a}^{\mathrm{i}}}{R T}\right) \cdot a_{\mathrm{i}}^{n_{\mathrm{i}}} \cdot f_{\mathrm{inh}}\right]\left(1-\Omega^{\mathrm{s}}\right)$,

where $A$ stands for the mineral reactive surface $\left(\mathrm{m}^{2} / \mathrm{m}^{3}\right.$ of soil), $k_{\mathrm{i}}$ and $E_{a}^{\mathrm{i}}$ are the dissolution rate constant and the activation energy for the i species promoted dissolution, and $a_{\mathrm{i}}$ and $n_{\mathrm{i}}$ stand for the activity of species $\mathrm{i}$ and the order of reaction with respect to $i$, respectively, and $f_{\text {inh }}$ describes the inhibiting effect of aqueous species on mineral dissolution. In this study $\mathrm{Al}^{3+}$ is considered as the main inhibiting species and the expression of $f_{\text {inh }}$ has been derived from Oelkers et al. (1994), Schott and Oelkers (1995) and Devidal et al. (1997). No provision has been made for a possible catalysis of dissolution rates by $\mathrm{CO}_{2}$ aqueous species since Golubev et al. (2005) have recently shown that these species have no direct effect on silicate dissolution rates. The consequence of departure from equilibrium on mineral dissolution/precipitation rate is accounted by the $\left(1-\Omega^{\mathrm{s}}\right)$ term, where $\Omega$ stands for the solution saturation index with respect to the particular solid and $\mathrm{s}$ is a stoichiometric number. Dissolution or precipitation occur depending if this function is positive or negative. WITCH does not include a nucleation model, and precipitation rate is assumed to be proportional to the reactive surface area of the mineral, an input parameter calculated from the observed relative abundance of minerals in each soil layer, and from the soil texture. As a consequence, only already present secondary minerals are able to precipitate, a reasonable assumption for a study that assumes the catchment is close to steady-state. The WITCH model includes kinetic laws for 31 minerals. Kinetic data for the minerals included in the present study are listed in Table 1 . Solubility products of primary and secondary minerals along with the enthalpy of their dissolution reactions are listed in Table 2.

The differential system is solved using a method adapted from the fully implicit Runge-Kutta 6th order method, with adaptative time step. The output are then injected at each time step into the speciation module that calculates the complete speciation of the solution for 17 chemical species $\left(\mathrm{H}^{+}\right.$, $\mathrm{OH}^{-}, \mathrm{HCO}_{3}{ }^{-}, \mathrm{CO}_{3}{ }^{2-}, \mathrm{H}_{2} \mathrm{CO}_{3}, \mathrm{Al}^{3+}, \mathrm{AlOH}^{2+}, \mathrm{Al}(\mathrm{OH})_{2}{ }^{+}$, $\mathrm{Al}(\mathrm{OH})_{4}^{-}, \mathrm{H}_{4} \mathrm{SiO}_{4}, \mathrm{H}_{3} \mathrm{SiO}_{4}{ }^{-}, \mathrm{H}_{2} \mathrm{SiO}_{4}{ }^{2-}, \mathrm{R}^{-}$standing for organic acid functional group, $\mathrm{PO}_{4}{ }^{3-}, \mathrm{HPO}_{4}{ }^{2-}, \mathrm{H}_{2} \mathrm{PO}_{4}{ }^{-}$, $\mathrm{H}_{3} \mathrm{PO}_{4}$ ). Reactions among aqueous species are assumed to occur instantaneously. Values of their equilibrium constants and enthalpies of reaction are taken from the SUPCRT database, except for $\mathrm{Al}$ aqueous species taken from (Castet et al., 1993; Wesolowski and Palmer, 1994).

\subsection{Coupling with a model of water and carbon cycles in forest ecosystems}

Several inputs of the WITCH model are unmeasurable. This is particularly the case for the vertical water fluxes and volumetric water contents at seasonal scale. Also element exchanges between soil solution and biological reservoirs throughout the soil horizons are required from day-today in order to perform seasonal runs. Finally, soil and below soil $\mathrm{CO}_{2}$ partial pressure were never measured on site. All these forcing functions (with an hourly time resolution) are calculated offline using the ASPECTS model (Rasse et al., 2001) (Fig. 1). Atmosphere-soil-plant exchanges of carbon in temperate Sylvae (ASPECTS) is a fully coupled scheme of the water and carbon cycles in the vegetation and soils of temperate forest ecosystems. The version used here does not contain nitrogen or other nutrient cycles. All fluxes and pools are calculated with a time step of $2 \mathrm{~min}$. This very short time step was necessary for the calculation of $\mathrm{CO}_{2}$ diffusion within the soil to be stable. Hourly meteorological data (air temperature, precipitation, global radiation, air relative humidity and wind speed) measured at the site were linearly interpolated at the model time step. Photosynthesis and transpiration are calculated separately for shaded and sunlit leaves (De Pury and Farquhar, 1997). The stomatal conductances of $\mathrm{CO}_{2}$ and $\mathrm{H}_{2} \mathrm{O}$ are related to the net assimilation of the leaves (Leuning, 1995). Photosynthetic assimilates transit through a carbohydrate pool before being allocated to other plant reservoirs (leaf, starch, branches, stem, coarse roots and fine roots). This allocation varies with stress factors (water, temperature, soil strength and soil aeration) influencing the development of forest vegetation. Growth rate of each plant carbon reservoir is given as the difference between carbon allocation and the carbon lost in respiration and litter production. The model can be integrated over several decades to simulate the growth of the trees. No heat budget is calculated at the surface, so that soil surface and leaf temperatures are assumed to be equal to the measured air temperature. All 
Table 1

Kinetic dissolution constants at $25^{\circ} \mathrm{C}\left(\mathrm{mol} / \mathrm{m}^{2} / \mathrm{s}\right)$ and activation energy $(\mathrm{kJ} / \mathrm{mol})$ of the dissolution reactions promoted by $\mathrm{H}^{+}, \mathrm{OH}^{-}$, water $(\mathrm{w})$ and organic ligands (L), as used in the WITCH model. Also shown is the reaction order with respect to $\mathrm{H}^{+}$and $\mathrm{OH}^{-}$promoted dissolution $\left(\mathrm{n}_{\mathrm{H}}\right.$, $\left.\mathrm{n}_{\mathrm{OH}}\right)$. Symbol $\sim$ stands for "no effect".

\begin{tabular}{|c|c|c|c|c|}
\hline & $\begin{array}{l}\mathrm{pk}_{\mathrm{H}} \\
\mathrm{E}_{\mathrm{a}} \mathrm{H} \\
n_{\mathrm{H}}\end{array}$ & $\begin{array}{l}\mathrm{pk}_{\mathrm{OH}} \\
\mathrm{E}_{\mathrm{a}} \mathrm{OH} \\
n_{\mathrm{OH}}\end{array}$ & $\begin{array}{l}\mathrm{pk}_{\mathrm{W}} \\
\mathrm{E}_{\mathrm{a}} \mathrm{w}\end{array}$ & $\begin{array}{l}\mathrm{pk}_{\mathrm{L}} \\
\mathrm{E}_{\mathrm{a}} \mathrm{L}\end{array}$ \\
\hline Albite $\left(\mathrm{An}_{6}\right)^{\mathrm{a}}$ & $\begin{array}{l}9.50 \\
60 \\
0.5\end{array}$ & $\begin{array}{c}9.95 \\
50 \\
0.3\end{array}$ & $\begin{array}{l}12.60 \\
67\end{array}$ & $\begin{array}{l}12.96 \\
59\end{array}$ \\
\hline Orthoclase $^{\mathrm{b}}$ & $\begin{array}{c}9.65 \\
60 \\
0.5\end{array}$ & $\begin{array}{l}10.70 \\
50 \\
0.3\end{array}$ & $\begin{array}{l}12.85 \\
67\end{array}$ & $\sim$ \\
\hline Quartz $^{\mathrm{c}}$ & $\begin{array}{l}\sim \\
\sim \\
\sim\end{array}$ & $\begin{array}{l}11.00 \\
85 \\
0.25\end{array}$ & $\begin{array}{l}13.40 \\
85\end{array}$ & $\sim$ \\
\hline Muscovite $^{\mathrm{d}}$ & $\begin{array}{l}12.20 \\
22 \\
0.17\end{array}$ & $\begin{array}{l}11.71 \\
22 \\
0.16\end{array}$ & $\begin{array}{l}\sim \\
\sim\end{array}$ & $\sim$ \\
\hline Biotite $^{e}$ & $\begin{array}{l}10.88 \\
35 \\
0.32\end{array}$ & $\begin{array}{l}\sim \\
\sim \\
\sim\end{array}$ & $\begin{array}{l}14.20 \\
35\end{array}$ & $\sim$ \\
\hline Kaolinite $^{\mathrm{f}}$ & $\begin{array}{l}12.45 \\
50 \\
0.38\end{array}$ & $\begin{array}{l}10.74 \\
40 \\
0.73\end{array}$ & $\begin{array}{l}14.43 \\
55\end{array}$ & $\sim$ \\
\hline Apatite $^{\mathrm{g}}$ & $\begin{array}{c}5.08 \\
34.7 \\
0.87\end{array}$ & $\begin{array}{l}\sim \\
\sim \\
\sim\end{array}$ & $\sim$ & $\sim$ \\
\hline All montmorillonites ${ }^{\mathrm{h}}$ & $\begin{array}{c}9.8 \\
48 \\
0.38\end{array}$ & $\begin{array}{l}\sim \\
\sim \\
\sim\end{array}$ & $\begin{array}{l}13.9 \\
55\end{array}$ & $\begin{array}{l}12.1 \\
48.3\end{array}$ \\
\hline Illite $^{i}$ & $\begin{array}{c}11.7 \\
46 \\
0.6\end{array}$ & $\begin{array}{l}12.3 \\
67 \\
0.6\end{array}$ & $\begin{array}{l}15 \\
14\end{array}$ & $\begin{array}{l}12.3 \\
48.3\end{array}$ \\
\hline
\end{tabular}

${ }^{\text {a }}$ Fitting within the framework of Eq. (3) of data reported by Blum and Stillings (1995) for albite. In agreement with these authors, it was assumed that the anorthite content $\left(\mathrm{An}_{6}\right)$ did not modify albite dissolution rate.

${ }^{\mathrm{b}}$ Fitting of data reported by Blum and Stillings (1995) for orthoclase.

${ }^{c}$ Dove (1994).

${ }^{\mathrm{d}}$ Fitting of data reported by Nagy (1995) for muscovite $(\mathrm{pH} \leqslant 8)$.

${ }^{\mathrm{e}}$ Fitting of data reported by Nagy (1995) for biotite.

${ }^{\mathrm{f}}$ Fitting of data reported by Nagy (1995) for kaolinite.

${ }^{\mathrm{g}}$ Fitting of data for fluoroapatite $(\mathrm{pH} \leqslant 7.5)$ from Guidry and Mackenzie (2003) and Chaïrat (2005)

${ }^{\mathrm{h}}$ Holmqvist (2001).

${ }^{\mathrm{i}}$ Köhler et al. (2003).

evaporative fluxes involved in the surface water budget are calculated from the saturation deficit using a resistance formalism. Precipitation interception by the foliage is represented by a reservoir which can be filled up to a maximum level. The proportion of wet foliage $\left(\varphi_{\text {wet }}\right)$, i.e., which contributes to the evaporation of intercepted water, is proportional to the size of this interception reservoir. When the maximum level is reached $\left(\varphi_{\text {wet }}=1\right)$, any excess water is evacuated as throughfall. Snow can accumulate in a surface reservoir. Precipitation is assumed to be snowfall when air temperature is below $0{ }^{\circ} \mathrm{C}$. Outputs from the snow reservoir are represented by snow melt, which is a linear function of air temperature and snow evaporation. Potential infiltration of water into the soil is the sum of direct precipitation (i.e., precipitation which reaches the ground without being intercepted by the foliage), throughfall (i.e., any excess water from the interception reservoir) and snow melt. Surface runoff occurs when potential infiltration exceeds the maximum amount of water that can be evacuated by vertical drainage from a small surface water reservoir $(5 \mathrm{~mm}$ layer with textural characteristics of the first soil layer). Soil evaporation is assumed to occur within this surface layer and is calculated using a resistance at the soil surface based on the work of Mahfouf and Noilhan (1991). Actual infiltration of water into the soil is then obtained as the difference between potential infiltration and the sum of surface runoff and soil evaporation.

The soil is divided into 6 layers along the vertical dimension consistently with the WITCH run design (see next section). Temperature, water content and $\mathrm{PCO}_{2}$ are calculated in each soil layer, as well as coarse and fine root biomass, litter and soil carbon amounts. Temperature is calculated by solving the heat diffusion equation assuming, as boundary conditions, that temperature is equal to the measured surface air temperature at the soil surface and to its measured annual mean surface temperature at the bottom of the lowest soil layer. Soil water content is computed by solving Richards' equation (Viterbo and Beljaars, 1995), setting the vertical water flux to the infiltration rate at the soil surface and imposing free drainage at the bottom. Soil textural data (\% sand, $\%$ silt, $\%$ clay) must be provided by the user for each soil layer. Soil $\mathrm{PCO}_{2}$ is calculated from the $\mathrm{CO}_{2}$ production rate (soil microbial respiration + root respiration) in each layer and by solving the diffusion equation (Fang and Moncrieff, 1999) with $\mathrm{PCO}_{2}$ set to the atmospheric value at the soil surface and a zero flux boundary condition at the bottom of the model soil.

The ASPECTS model has been successfully tested on two Belgian forested sites (Vielsalm and Braschaat), where it was shown to be able to simulate the net ecosystem exchange for several years of data (Rasse et al., 2001). Importantly, one of these sites (Vielsalm) has a similar forest cover (beech trees and Douglas firs) to the Strengbach (beech and Norway spruce trees) and exhibits similar temperatures and precipitation conditions.

\subsection{Sites, run design, forcing functions and parameters}

The Strengbach forested catchment ( 80 ha area) is located on the eastern part of the Vosges Mountains (North East of France), $58 \mathrm{~km} \mathrm{SW}$ from Strasbourg. The elevation ranges from $883 \mathrm{~m}$ at the outlet to $1146 \mathrm{~m}$ at the catchment divide. The slopes are rather steep. The climate is temperate oceanic mountainous and westerly winds dominate. The monthly average of daily mean temperature ranges from -2 to $14{ }^{\circ} \mathrm{C}$ (Probst et al., 1990). The mean annual rainfall is about $1400 \mathrm{~mm}$ (Probst and Viville, 1997). Most of the rainfall occurs in 
Table 2

Equilibrium constants at $25^{\circ} \mathrm{C}$ and enthalpies of reaction for dissolution of minerals involved in the present study

\begin{tabular}{|c|c|c|c|}
\hline & Dissolution reaction & $\mathrm{pK}_{\mathrm{eq}}$ & $\Delta H_{\mathrm{R}}^{0}(\mathrm{~kJ} / \mathrm{mol})$ \\
\hline Albite An 6\% & Assimilated to albite: $\mathrm{NaAlSi}_{3} \mathrm{O}_{8}+4 \mathrm{H}_{2} \mathrm{O}+\mathrm{H}^{+} \rightarrow \mathrm{Na}^{+}+\mathrm{Al}^{3+}+3 \mathrm{H}_{4} \mathrm{SiO}_{4}+$ calcium release & -2.29 & -73.82 \\
\hline Orthoclase & $\mathrm{KAlSi}_{3} \mathrm{O}_{8}+4 \mathrm{H}_{2} \mathrm{O}+4 \mathrm{H}^{+} \rightarrow \mathrm{K}^{+}+\mathrm{Al}^{3+}+3 \mathrm{H}_{4} \mathrm{SiO}_{4}$ & 0.022 & -49.93 \\
\hline Quartz & $\mathrm{SiO}_{2}+2 \mathrm{H}_{2} \mathrm{O} \rightarrow \mathrm{H}_{4} \mathrm{SiO}_{4}$ & 3.98 & 25.06 \\
\hline Biotite $^{\mathrm{b}}$ & $\mathrm{KMg}_{1.5} \mathrm{Fe}_{1.5} \mathrm{AlSi}_{3} \mathrm{O}_{10}(\mathrm{OH})_{2}+10 \mathrm{H}^{+} \rightarrow \mathrm{K}^{+}+1.5 \mathrm{Mg}^{2+}+1.5 \mathrm{Fe}^{2+}+\mathrm{Al}^{3+}+3 \mathrm{H}_{4} \mathrm{SiO}_{4}$ & -32.87 & -55.6 \\
\hline Kaolinite ${ }^{\mathrm{a}}$ & $\mathrm{Al}_{2} \mathrm{Si}_{2} \mathrm{O}_{5}(\mathrm{OH})_{4}+6 \mathrm{H}^{+} \rightarrow 2 \mathrm{Al}^{3+}+2 \mathrm{H}_{4} \mathrm{SiO}_{4}+2 \mathrm{H}_{2} \mathrm{O}$ & -7.43 & -147.7 \\
\hline Halloysite $^{\mathrm{a}}$ & $\mathrm{Al}_{2} \mathrm{Si}_{2} \mathrm{O}_{5}(\mathrm{OH})_{4}+6 \mathrm{H}^{+} \rightarrow 2 \mathrm{Al}^{3+}+2 \mathrm{H}_{4} \mathrm{SiO}_{4}+2 \mathrm{H}_{2} \mathrm{O}$ & -12.5 & -166.6 \\
\hline Apatite ${ }^{c}$ & $\mathrm{Ca}_{10}\left(\mathrm{PO}_{4}\right)_{6} \mathrm{~F}_{2}+12 \mathrm{H}^{+} \rightarrow 10 \mathrm{Ca}^{2+}+6 \mathrm{H}_{2} \mathrm{PO}_{4}^{-}+2 \mathrm{~F}^{-}$ & -49.99 & -110.0 \\
\hline Ca-montmoril & $\mathrm{Si}_{4} \mathrm{O}_{10}(\mathrm{OH})_{2} \mathrm{Mg}_{0.33} \mathrm{Al}_{1.67} \mathrm{Ca}_{0.165}+6 \mathrm{H}^{+}+4 \mathrm{H}_{2} \mathrm{O} \rightarrow 4 \mathrm{H}_{4} \mathrm{SiO}_{4}+1.67 \mathrm{Al}^{3+}+0.33 \mathrm{Mg}^{2+}+0.165 \mathrm{Ca}^{2+}$ & -2.53 & -81.65 \\
\hline Na-montmoril & $\mathrm{Si}_{4} \mathrm{O}_{10}(\mathrm{OH})_{2} \mathrm{Mg}_{0.33} \mathrm{Al}_{1.67} \mathrm{Na}_{0.33}+6 \mathrm{H}^{+}+4 \mathrm{H}_{2} \mathrm{O} \rightarrow 4 \mathrm{H}_{4} \mathrm{SiO}_{4}+1.67 \mathrm{Al}^{3+}+0.33 \mathrm{Mg}^{2+}+0.33 \mathrm{Na}^{+}$ & -2.58 & -74.70 \\
\hline Mg-montmoril & $\mathrm{Si}_{4} \mathrm{O}_{10}(\mathrm{OH})_{2} \mathrm{Mg}_{0.33} \mathrm{Al}_{1.67} \mathrm{Mg}_{0.165}+6 \mathrm{H}^{+}+4 \mathrm{H}_{2} \mathrm{O} \rightarrow 4 \mathrm{H}_{4} \mathrm{SiO}_{4}+1.67 \mathrm{Al}^{3+}+0.50 \mathrm{Mg}^{2+}$ & -2.49 & -86.44 \\
\hline K-montmoril & $\mathrm{Si}_{4} \mathrm{O}_{10}(\mathrm{OH})_{2} \mathrm{Mg}_{033} \mathrm{Al}_{167} \mathrm{Na}_{0.33}+6 \mathrm{H}^{+}+4 \mathrm{H}_{2} \mathrm{O} \rightarrow 4 \mathrm{H}_{4} \mathrm{SiO}_{4}+1.67 \mathrm{Al}^{3+}+0.33 \mathrm{Mg}^{2+}+0.33 \mathrm{~K}^{+}$ & -2.24 & -69.66 \\
\hline Illite $^{\mathrm{d}}$ & $\begin{array}{l}\mathrm{Si}_{3.4} \mathrm{O}_{10}(\mathrm{OH})_{2} \mathrm{Mg}_{0.02} \mathrm{Al}_{2.38} \mathrm{Ca}_{0.01} \mathrm{~K}_{0.44}+7.64 \mathrm{H}^{+}+2 \mathrm{H}_{2} \mathrm{O} \rightarrow 3.4 \mathrm{H}_{4} \mathrm{SiO}_{4}+2.38 \mathrm{Al}^{3+}+0.02 \mathrm{Mg}^{2+} \\
+0.01 \mathrm{Ca}^{2+}+0.44 \mathrm{~K}^{+}\end{array}$ & -6.82 & -146.31 \\
\hline
\end{tabular}

Unless otherwise specified, data for minerals and aqueous species are from SUPCRT (SPEQ03.DAT) except for Al ${ }^{3+}$ (Castet et al., 1993; Wesolowski and

Palmer, 1994) and $\mathrm{H}_{4} \mathrm{SiO}_{4}$ (Walther and Hegelson, 1977).

${ }^{a}$ Drever (1997).

${ }^{\mathrm{b}}$ Biotite Gibbs free energy calculated in this study assuming a regular solid solution between annite and phlogopite (Fe atomic fraction in M1 sites of 0.9 and $\mathrm{W}=9 \mathrm{~kJ}$, THERMOCALC) and end-members thermodynamic data from SUPCRT.

c Guidry and Mackenzie (2003).

${ }^{d}$ Illite Gibbs free energy calculated in this study based on the electronegativity scale method (Vieillard, 2000).

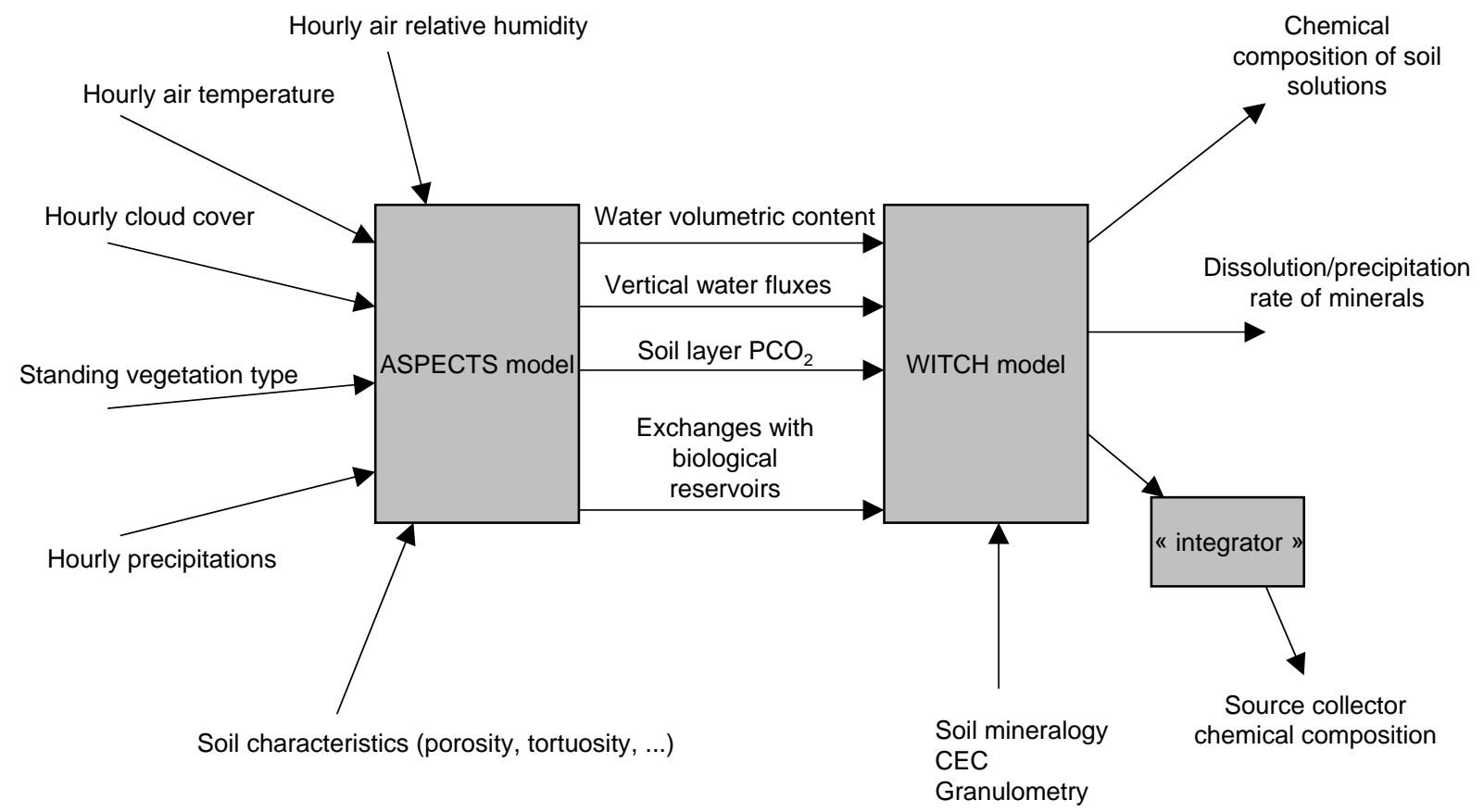

Fig. 1. Schematic view of the coupling between the ASPECTS biospheric model and the WITCH geochemical model, including the main forcing functions of ASPECTS, and the output of WITCH. The coupling is based on an hourly timescale.

spring whereas the driest season is in autumn. The total runoff averages $853 \mathrm{~mm}$ for the 1986-1995 period (Probst et al., 1995), which corresponds to a mean annual discharge of $21.7 \mathrm{~L} / \mathrm{s}$. The bedrock is a base poor leucogranite (the Brézouard granite) aged of $315 \pm 7 \mathrm{Ma}$ (Bonhomme, 1967). This granite is coarse grained and has undergone hydrothermal alteration 183.9 My ago, which is particularly obvious on the south-facing slope of the catchment (El Gh'Mari, 1995). Hydrothermal alteration has caused depletion of plagioclase, and precipitation of illite and hematite in the fractured granite. At the upper margin of the catchment, a banded gneiss lies in contact with the granite. The soils are rather deep ( $80 \mathrm{~cm}$ in average), sandy and stony and overlay a saprolite, which can reach $10 \mathrm{~m}$ depth in places. They belong to the brown acidic to ochreous podzolic soils series. 
Both sides of the catchment have been equipped with an experimental site (respectively, PP on the south-facing slope, and HP on the north-facing slope of the catchment). Both sites are characterized by a granitic mineralogy (Brezouard granite). Mineral composition of the soil layers for both sites are shown in Fig. 2. The relative abundance of octahedral Ca-, Na-, Mg- and K-montmorillonites within the montmorillonite pole is not known, and we assume that all the four different montmorillonites are equally abundant (1/4 of the total smectite abundance). Note that apart from the mineralogical composition of montmorillonites, the exchangeable cation pool is dominated by the $\mathrm{H}^{+}$ and $\mathrm{Al}^{3+}$ cations, particularly within the upper soil layers, due to the atmospheric acidic input. The vegetation consists in 130-year-old beech trees (HP), which cover about $20 \%$ of the catchment surface and are exclusively located on the northern flank, and in 80-year-old spruces (PP) covering the remaining $80 \%$ of the catchment. The PP site is located on the slightly hydrothermalized part of the catchment.

Separate model simulations have been performed on the HP and PP sites, assuming that they ideally represent the two mineralogical and ecological poles of the Strengbach (HP for the non hydrothermalized granite below beech trees and PP for the hydrothermalized granite below spruces). Indeed, even for a monolithological catchment, the mineralogy is a function of the geomorphology, the vegetation cover, the exposure and the hydrothermal
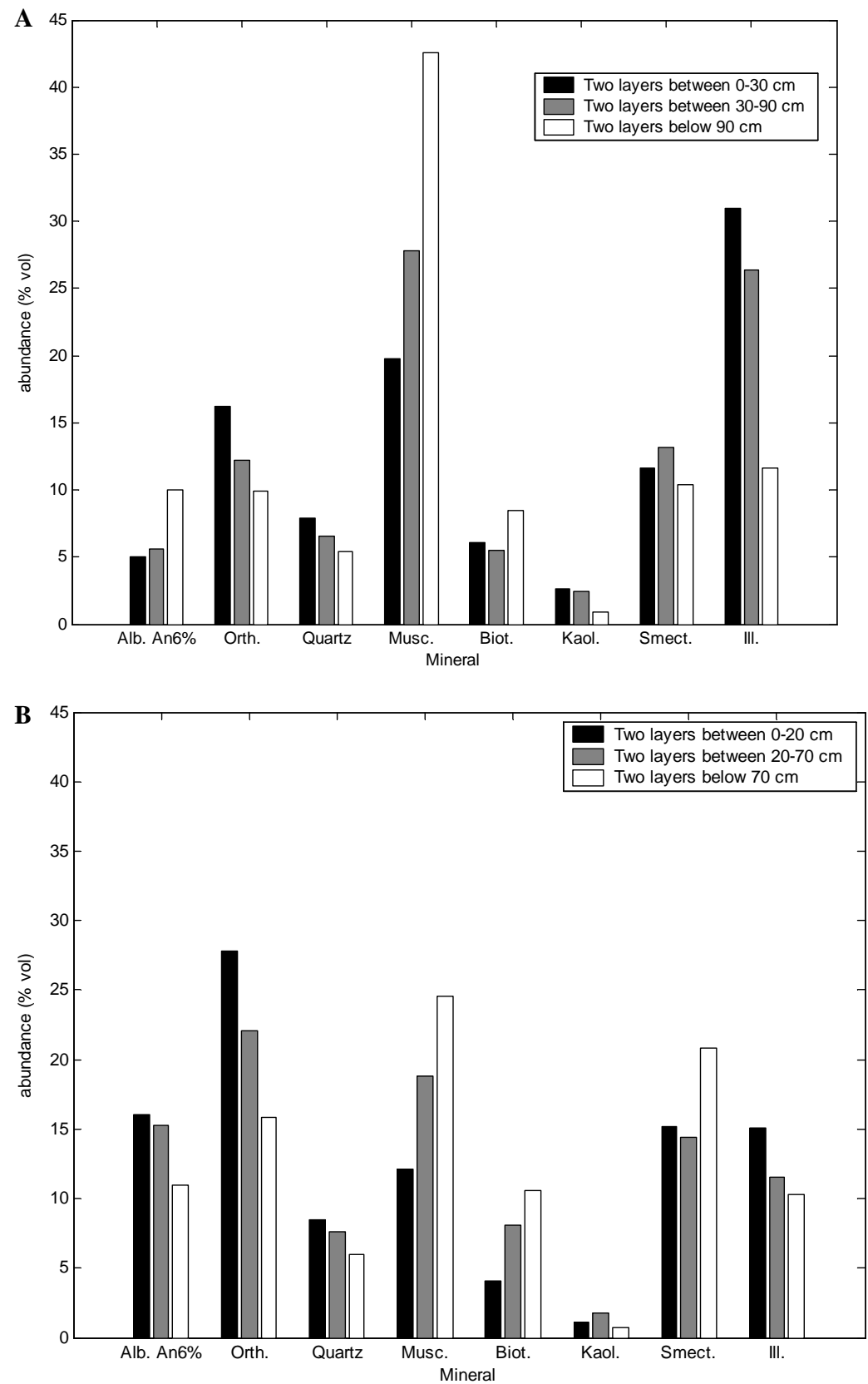

Fig. 2. Mineralogy for sites (A) PP and (B) HP used in the simulations. The reference run was performed without apatite. 
history. This is why all simulations were doubled (HP and PP) to account for this variability, and to ensure that the upscaling procedure to the whole catchment based on the results obtained for the PP and HP sites is valid. The soil profile is represented by 6 layers in the ASPECTS and WITCH models, extending down, respectively, to 150 (HP) and $180 \mathrm{~cm}(\mathrm{PP})$. The layers have been defined following Fichter (1997). Soil characteristics, including texture and density, are summarized in Table 3. Soil solutions were sampled and analyzed from October 1994 to October 1995 at 10 and 60 (PP) or 70 (HP) cm depth, with a two week sampling interval (Probst et al., 2000). These measurements include major cations, aluminium, aqueous silica and $\mathrm{SO}_{4}{ }^{2-}$ concentrations. Throughfall chemical compositions have been measured with a 15-day sampling interval for each site. DOC content is fixed within each layer (Table 3 ) in agreement with the estimations from Dambrine et al. (1995). Mineral reactive surface area $A\left(\mathrm{~m}^{2} /\right.$ $\mathrm{m}^{3}$ ) has been calculated from soil texture (Table 3), according to a parametric law (Sverdrup and Warfinge, 1995) as an approach of the BET surface (Hodson et al., 1998):

$A=\left(8.0 x_{\text {clay }}+2.2 x_{\text {silt }}+0.3 x_{\text {sand }}+0 x_{\text {coarse }}\right) \cdot \rho$,

where $x_{\text {clay }}, x_{\text {silt }}, x_{\text {sand }}$ and $x_{\text {coarse }}$ represent the textural fractions of the soils, respectively, clay, silt, sand and coarse materials so that $x_{\text {clay }}+x_{\text {silt }}+x_{\text {sand }}+x_{\text {coarse }}=1$. $\rho$ is the soil density in $\mathrm{g} / \mathrm{m}^{3}$ (Table 3). As noted by Gautier et al. (2001) and Sverdrup and Warfinge (1995), the actual reactive surface might be lower than this total surface, but there is no real standard method to fix the reactive surface of the minerals. So using the parametric law appears to be the only alternative. The relative ratio between the BET and the effective reactive surface is a specific property of the mineral investigated which is generally not known. Coherence of calculations performed in this study was ensured by normalizing all mineral dissolution rate constants to BET surface area.
Reactive surface area is distributed among the various minerals according to their volume abundance, itself calculated from the weight abundance measured within the 6 top layers (Fichter et al., 1998a). The texture as a function of depth is taken from Aubert (2001), and the relative proportions of clay, silt and sand materials used in the model are given in Table 3. CEC is fixed to the following values for the first four layers from top to bottom: $7.86 \times 10^{-5}$, $7.70 \times 10^{-5}, 5.02 \times 10^{-5}$ and $1.79 \times 10^{-5} \mathrm{keq} / \mathrm{kg}$ (Fichter, 1997). Below layer 4, CEC is estimated through linear extrapolation. Finally, Gapon exchange constant are taken from Posch et al. (2003). The constants given for sandy, silt and clay soils are weighted by the measured texture for each layer.

Hourly meteorological data measured from October 1994 to September 1995 are used to force the models. ASPECTS is integrated over the lifetime of the trees from seedlings to the current adult forest by forcing each year of model-time with the 1994-1995 meteorological dataset. The daily runoff predicted by the hydrological sub-model of ASPECTS is compared in Fig. 3 to the runoff derived from the measured stream discharge. The overall shape and amplitude of the model runoff curve is relatively satisfactory compared to the data. However, it must be stressed that the model runoff corresponds to the vertical drainage at the bottom of the deepest model soil layer (at HP or PP sites), whereas the data represent daily stream discharge. The peaks of these two quantities may be significantly out of phase due to the existence of a saturated zone near the outlet of the Strengbach catchment (which reacts rapidly to rainfall), as well as to potential water storage in underground reservoirs. Fig. 4 shows the $\mathrm{PCO}_{2}$ calculated by ASPECTS in the different soil layers of HP and PP sites. Soil $\mathrm{PCO}_{2}$ was not measured on site, so that this critical parameter cannot be strictly validated. On a mean annual basis, calculated $\mathrm{PCO}_{2}$ reaches, respectively, 3.35 and 7 times the atmospheric pressure of $320 \times 10^{-6}$

Table 3

Percentage of clay/silt/sand of the reactive minerals as a function of depth for HP and PP horizons

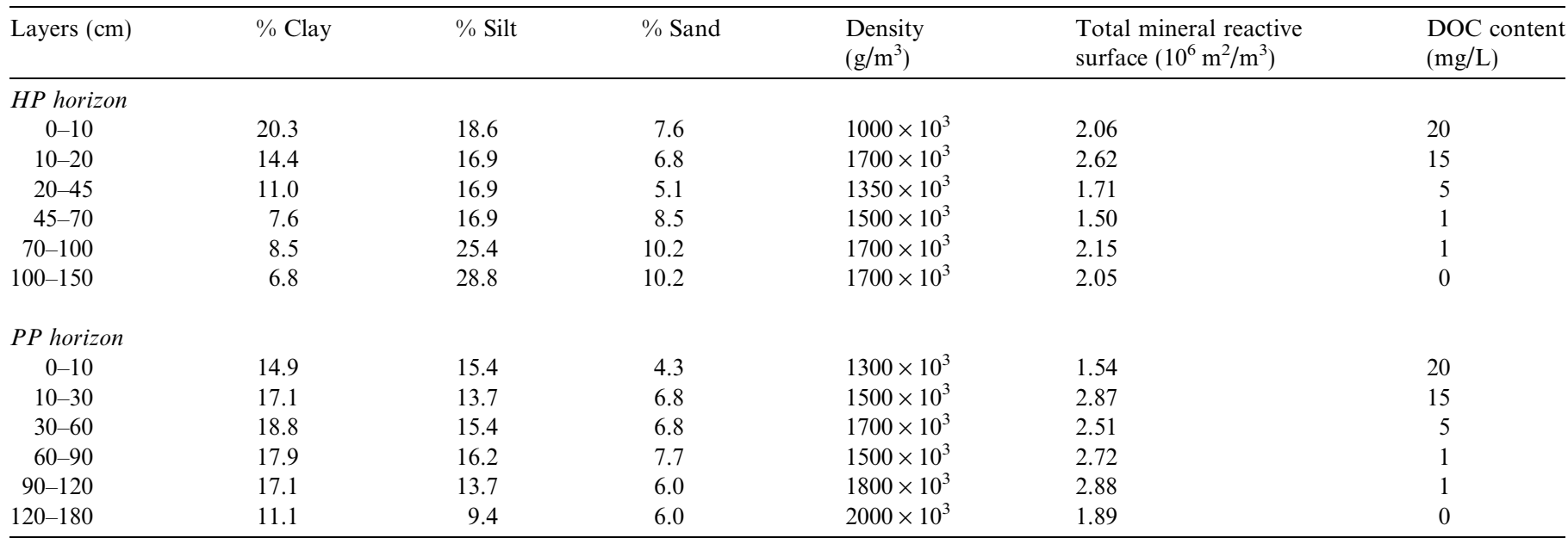

Also mentioned is the mineral reactive surface and the DOC content. 


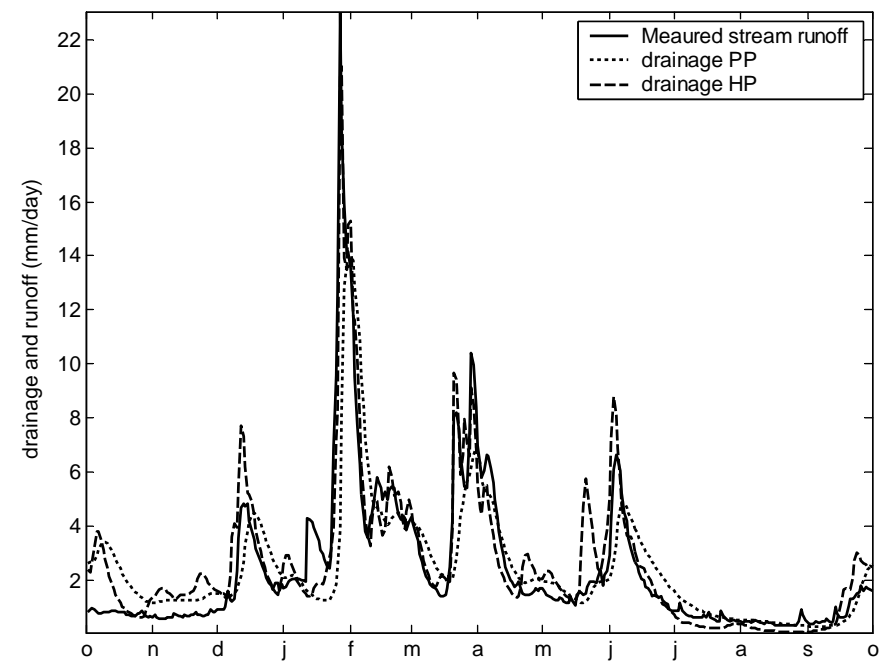

Fig. 3. The Strengbach runoff as measured at the site between October 1994 and September 1995 and compared to the drainage calculated by ASPECTS at the bottom of the deepest model soil layer for HP and PP sites.

atmosphere (this atmospheric value corresponds to the $\mathrm{CO}_{2}$ pressure calculated at the average elevation of the site; it is assumed constant in time over the whole simulation) for the HP and PP lowest soil horizons, respectively (layer $6,100-150$ and $120-180 \mathrm{~cm}$ depth, respectively). Uptake of $\mathrm{Ca}^{2+}, \mathrm{Mg}^{2+}, \mathrm{K}^{+}$, phosphorus and sulfur by vegetation is assumed proportional to the gross primary productivity calculated by ASPECTS and the measured mean $\mathrm{Ca} / \mathrm{C}$ $\left(1.12 \times 10^{-3} \mathrm{~mol} / \mathrm{mol}\right), \mathrm{Mg} / \mathrm{C}\left(2.54 \times 10^{-4} \mathrm{~mol} / \mathrm{mol}\right), \mathrm{K} / \mathrm{C}$ $\left(6.11 \times 10^{-4} \mathrm{~mol} / \mathrm{mol}\right), \quad \mathrm{P} / \mathrm{C}\left(1.41 \times 10^{-4} \mathrm{~mol} / \mathrm{mol}\right)$ and $\mathrm{S} / \mathrm{C}\left(2.23 \times 10^{-3} \mathrm{~mol} / \mathrm{mol}\right)$ in the catchment living trees older than 80 years. Release of these elements is calculated proportionally to the release of carbon through oxidation of organic carbon, itself calculated by the ASPECTS model within each soil horizon. The net annual exchange of cations between vegetation and soil solutions is assumed to be equal to zero (steady-state ecosystem). Furthermore, this steady-state hypothesis also implies that the seasonal base saturation on the exchange complex fluctuates around a constant mean value, with no long term trend. The only impact of the exchange complex on the model results is a dampening of the calculated seasonal fluctuations of the base cation concentrations in soil solution (except for $\mathrm{Na}^{+}$that is not adsorbed on the exchange complex).

A deep layer box (layer 7, Fig. 5) has been added within the WITCH model on both HP and PP site, from, respectively, 1.5 to $10 \mathrm{~m}$, and 1.8 to $10 \mathrm{~m}$. This deep box accounts for deep weathering processes within the catchment, where the bedrock is in contact with percolating solutions. DOC within the deep box is fixed to $0 \mathrm{mg} / \mathrm{L}$, and soil $\mathrm{PCO}_{2}$ to a constant value equal to the mean annual value within the deepest soil horizon (layer 6). The value of layer 7 temperature is fixed to the catchment annual mean air temperature. Soil water content and vertical water fluxes are assumed to be the same as in layer 6 (the ASPECTS model runs do not extend so deep). As a result, the mean residence time of water within layer 7 is about 8 months. Similarly, mineralogy and grain size distribution within this deep box is assumed to be the same as in layer 6 .

A first set of WITCH simulations have been performed on both HP and PP locations. The initial conditions for each run are calculated through a 20 -year run with mean annual temperature, atmospheric deposition, soil water content, vertical water fluxes and exchange reactions assumed at steady-state. This procedure allows the seasonal
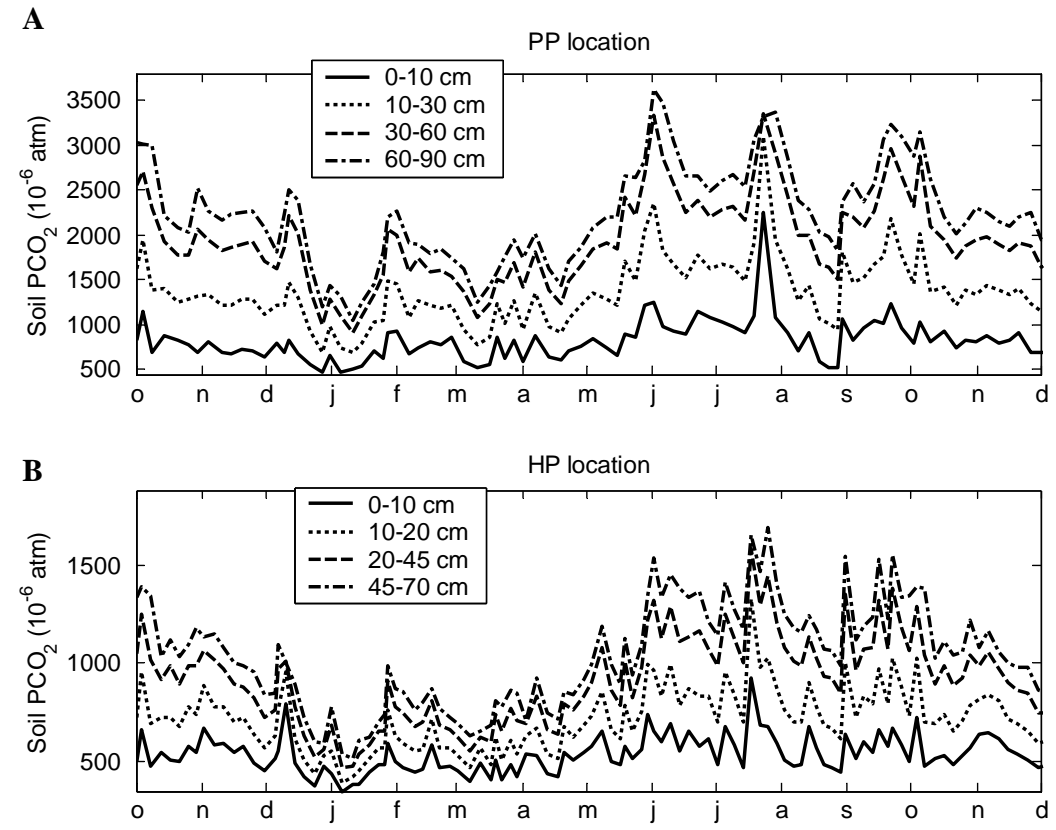

Fig. 4. Simulated soil $\mathrm{PCO}_{2}$ by the ASPECTS model for the four top soil layers of the HP and PP locations as a function of date from October 1994 to December 1995. Below the four top layers, the $\mathrm{PCO}_{2}$ evolution is very close to the layer 4 calculated $\mathrm{PCO}_{2}$. 


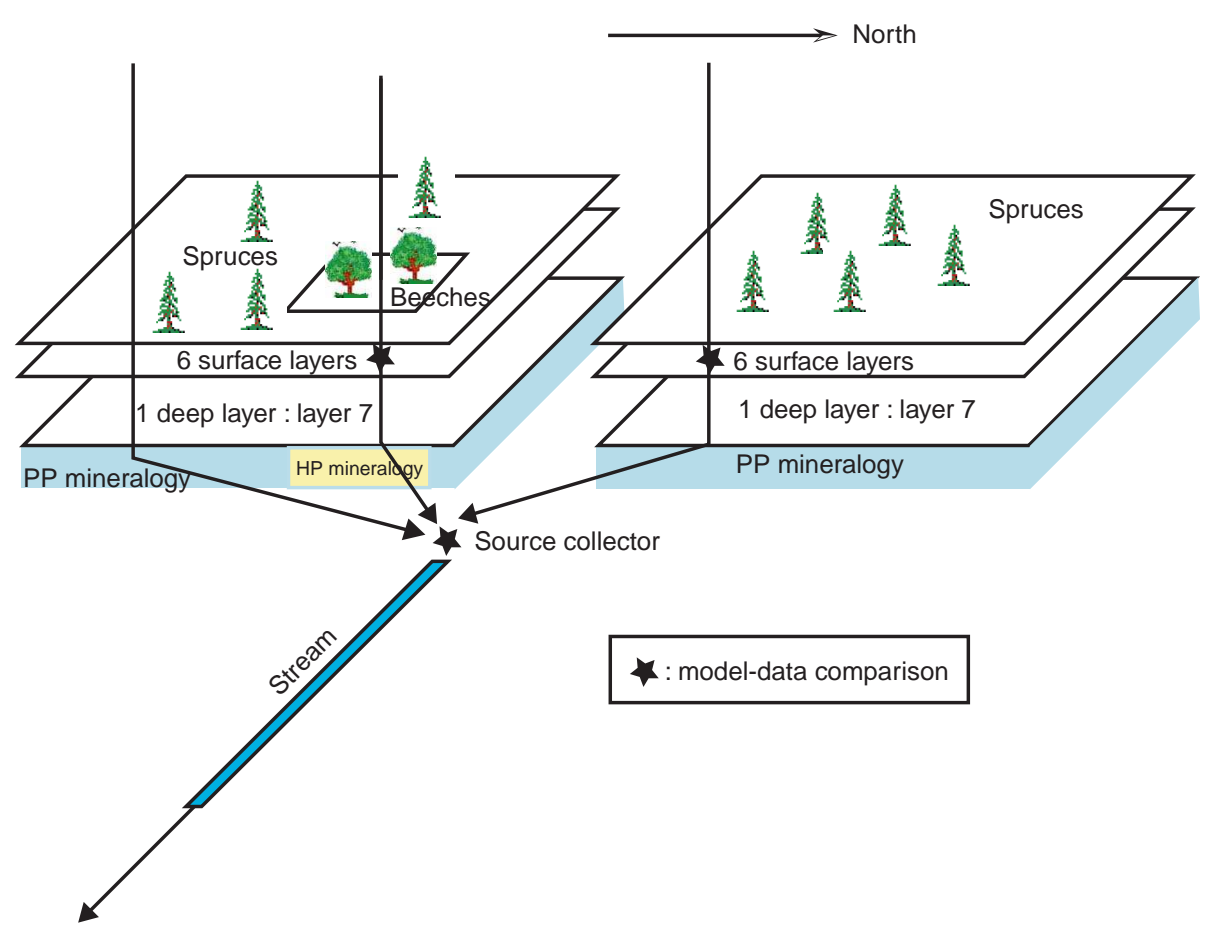

Fig. 5. The Strengbach catchment as seen by the WITCH model. The WITCH model was run for two locations (HP and PP), and results were compared with available data for the soil horizons. Then the upscaling procedure assumes that the mineralogy below the PP site (covered by spruce) can be extended to the complete area covered by the same vegetation type. The black stars stand for data-model comparison tests (at the soil level on the HP and PP location, and at the spring collector).

simulation to be started from a mean state of the system close to steady-state. However, because of the nonlinearity of the processes described within the WITCH model (including the dissolution/precipitation kinetics and exchange reactions), the mean steady-state calculated from seasonal runs differs from the steady-state calculated by mean annual runs. This required the seasonal simulations to be performed at least for several years so that initial conditions are finally relaxed. The model is run with seasonal forcing functions (temperature, soil $\mathrm{PCO}_{2}$, water volumetric contents, vertical water fluxes, uptake and release of elements by vegetation, atmospheric deposition, all calculated by ASPECTS or measured in the field from October 1st 1994 to September 30th 1995) until steady-state is reached (achieved within 5 simulated years). These seasonal forcing functions are repeated from year to year.

A first validation of the model was performed by comparing calculated composition of soil solutions to lysimetric soil solution measurements at 10 and $70 \mathrm{~cm}$ (HP) and 10 and $60 \mathrm{~cm}$ (PP) (Fig. 5). This procedure is essentially aimed at testing the "surface" geochemical sub-model of WITCH.

\section{Results of the reference simulation}

\subsection{Reference run, PP location}

The reference run (REF simulation) was performed using the mineralogy summarized in Fig. 2, without the presence of trace minerals in the model layers. Model mean annual aqueous concentrations compare well to available data both at 10 and $60 \mathrm{~cm}$, except for a slight aqueous silica overestimation at $10 \mathrm{~cm}$, and a slight calcium underestimation at $60 \mathrm{~cm}$ depth (Figs. 6A and B). Calculated mean annual $\mathrm{pH}$ equals 3.91 at $10 \mathrm{~cm}$ depth (in agreement with the observed 4.0), and 4.84 at $60 \mathrm{~cm}$ depth (observed 4.4).

Mean annual $\mathrm{SiO}_{2}$ overestimation at $10 \mathrm{~cm}$ essentially comes from a significant overshoot from the end of July to the end of August that is related to a sharp decrease in rainfall and vertical drainage (Fig. 7). Since almost no precipitation occurred during August 1995, modelled soil became extremely dry. Soil volumetric water content between 10 and $30 \mathrm{~cm}$ (layer 2) decreases from a roughly constant annual value of $0.26-0.12 \mathrm{~m}^{3} / \mathrm{m}^{3}$ in August. As a result, evapotranspiration dominates the surface hydrological budget. The vertical water flux is inverted, going from the bottom to the top, bringing up and thus concentrating aqueous $\mathrm{SiO}_{2}$ in the top layer. The same feature is observed for all cations at $10 \mathrm{~cm}$ depth, in apparent disagreement with the lysimetric soil solution data. The modelled exchangeable cations are less sensitive to this hydrological event. However, lysimetric plates may not reliably capture such features occurring in extremely dry conditions, since they only collect downward water fluxes.

Apart from this discrepancy, the general seasonal behaviour at $60 \mathrm{~cm}$ depth is well reproduced. $\mathrm{SiO}_{2}, \mathrm{Ca}^{2+}$ and $\mathrm{Mg}^{2+}$ concentrations display a general decrease from December to roughly June, and an increasing trend from 

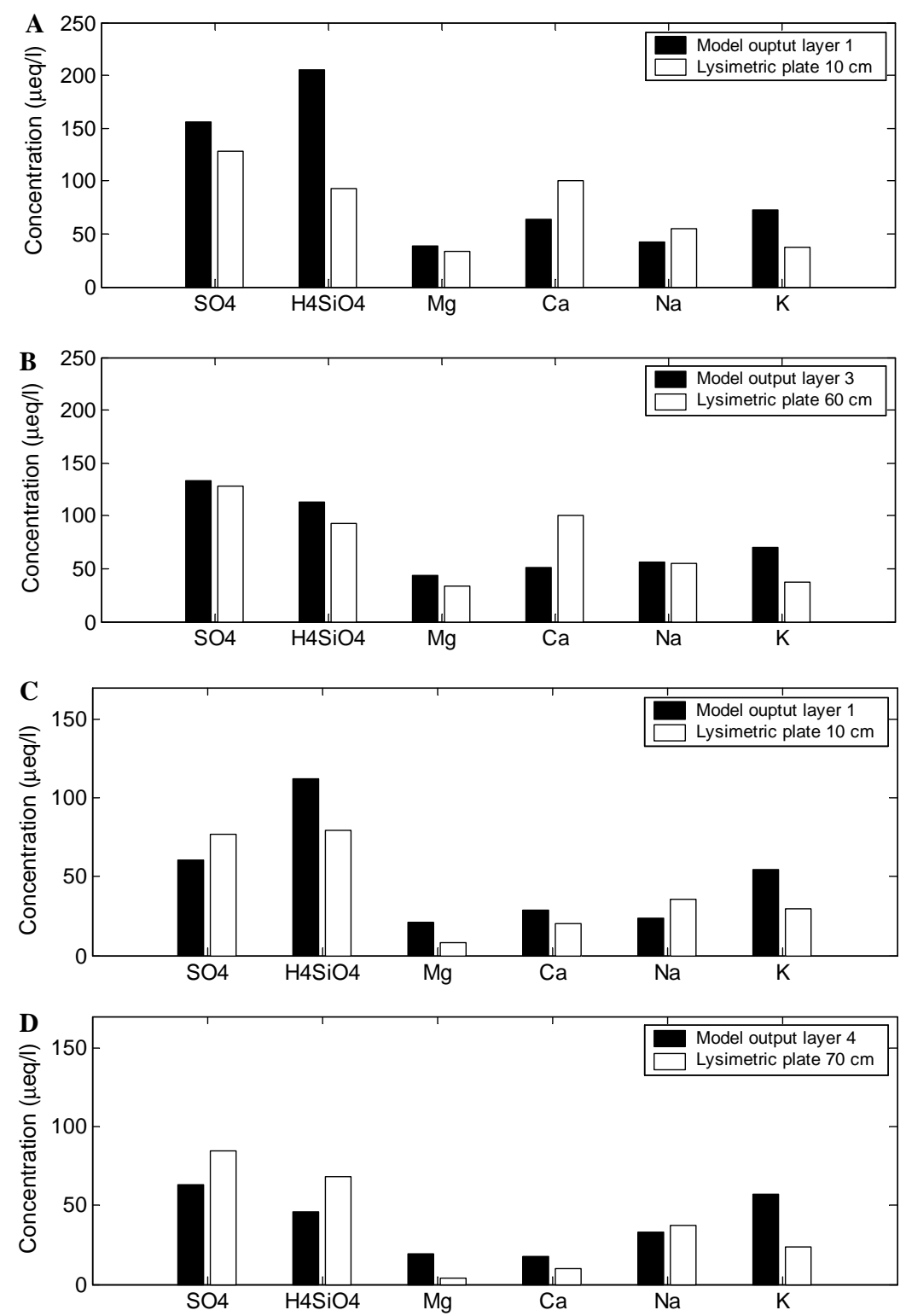

Fig. 6. Mean annual simulated concentrations (REF simulation) of sulphate ( $\mu \mathrm{eq} / \mathrm{L}$ ), $\mathrm{H}_{4} \mathrm{SiO}_{4}(\mu \mathrm{mol} / \mathrm{L}$ ) and major cations ( $\mu$ eq/L) in black, compared to the mean annual data acquired on lysimetric plates in white. (A) PP site $10 \mathrm{~cm}$ depth, (B) PP site $60 \mathrm{~cm}$ depth, (C) HP site $10 \mathrm{~cm}$ depth and (D) HP site $70 \mathrm{~cm}$ depth.

June to October (Fig. 7). Seasonal fluctuations of $\mathrm{Na}^{+}$concentration are not so well reproduced by the model (not shown), although the mean annual value is.

Calculated summer (mean June-July-August values) weathering profile shows that all secondary phases dissolve down to $10 \mathrm{~cm}$ depth, producing most of aqueous silica present in the top soil layers (Fig. 8A). Below $10 \mathrm{~cm}, \mathrm{Ca}-$ and $\mathrm{Mg}$-montmorillonites precipitate, while Na-montmorillonite still dissolves down to the base of the soil profile ( $1.8 \mathrm{~m}$ depth). The summer profile explains why aqueous $\mathrm{SiO}_{2}$ accumulates in the top layer when vertical water fluxes are inverted (August 1995), since aqueous $\mathrm{SiO}_{2}$ is then trapped within the shallow production layers (where all secondary phases dissolve).
Summer and winter (December-January-February) weathering profiles largely differ for the upper soil layers. In winter, all secondary phases dissolve down to $30 \mathrm{~cm}$. Below this depth, interstitial fluids become slightly supersaturated with respect to $\mathrm{Ca}$ - and $\mathrm{Mg}$-montmorillonites (not shown). The overall contribution of all secondary phases to the silicon budget is positive (corresponding to a dissolution) for each soil layer down to $90 \mathrm{~cm}$ depth, and negative below (Fig. 9A). In summer, the net silicon budget for secondary phases is positive for the top layers, but severely negative from 30 to $60 \mathrm{~cm}$ depth (Fig 9B). Dissolution rates of secondary minerals (expressed in $\mathrm{kmol} / \mathrm{m}^{2} / \mathrm{s}$ of silicon) are reduced by a factor of 1.6 in the $0-10 \mathrm{~cm}$ horizon in winter, compared to summer. 

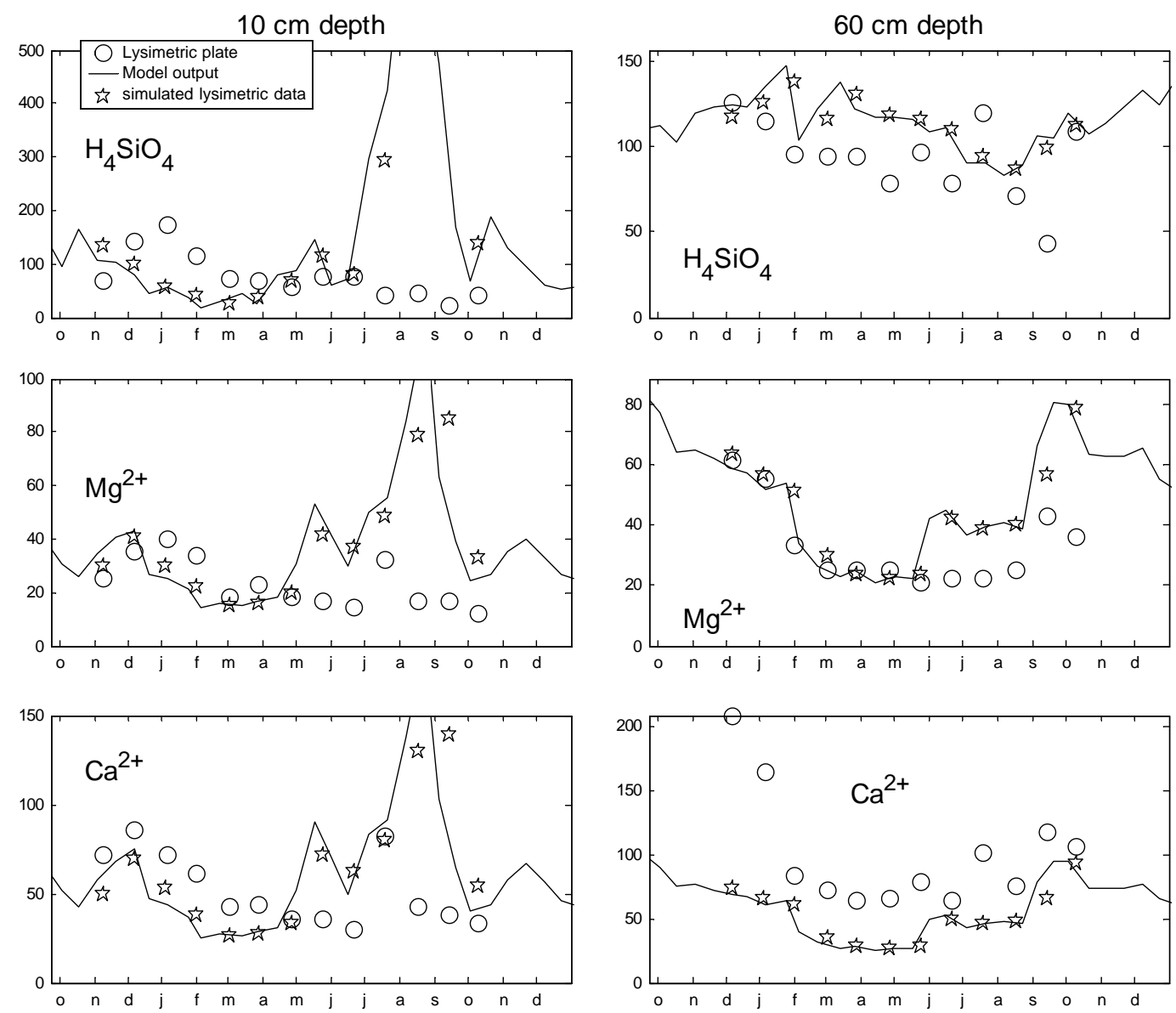

Fig. 7. Simulated $\mathrm{H}_{4} \mathrm{SiO}_{4}, \mathrm{Mg}^{2+}$ and $\mathrm{Ca}^{2+}$ concentration as a function of time for the PP location (REF simulation). Dots stand for data acquired on lysimetric plates, solid line is the model output, and the stars represent the simulated concentrations on lysimetric plates calculated from model output (model output are integrated over the time interval between two lysimetric plate measurements and weighted by the calculated vertical water fluxes).

The silicon budget down to $180 \mathrm{~cm}$ depth is largely controlled by the interaction between secondary phases and soil solutions (Figs. 9A and B). Silica release by primary mineral dissolution (mainly biotite) is only significant for the deep layer (layer 7, 1.80-10 m).

\subsection{Reference run, HP location}

Annual mean concentrations calculated for the HP location again roughly matches the lysimetric data (Figs. 6C and D). The main difference between model and data lies in the underestimation by the model of aqueous silica concentration at $70 \mathrm{~cm}$ depth. Mean annual $\mathrm{pH}$ is around 4.41 for the top layer (4.24 measured), and 5.35 (4.95 measured) at $70 \mathrm{~cm}$ depth. The August overshoot in $\mathrm{SiO}_{2}$ at $10 \mathrm{~cm}$ depth is also observed although less pronounced (Fig. 10). Exchangeable cations do not show any simultaneous peak. The main reason for this divergence is the difference in the standing vegetation from PP to HP. Evapotranspiration appears to be less important during dry months for beeches located on the more humid North slope than for spruces.

The model roughly matches the measured seasonal fluctuations for $\mathrm{Mg}^{2+}, \mathrm{Ca}^{2+}$ and $\mathrm{SiO}_{2}$ (particularly at $10 \mathrm{~cm}$ depth, and except for the August overshoot), although it slightly overestimates $\mathrm{Ca}^{2+}$ and $\mathrm{Mg}^{2+}$ concentrations (Fig. 10). $\mathrm{Mg}^{2+}$ concentration overestimation is essentially linked to higher $\mathrm{Mg}^{2+}$ concentration in throughfall (mean $11 \mu \mathrm{eq} / \mathrm{L})$ than in measured soil solutions $(8 \mu \mathrm{eq} / \mathrm{L})$, and possibly to overevaluated dissolution of smectites in the upper soil layer. Interestingly, calculated $\mathrm{Na}^{+}$concentration at $10 \mathrm{~cm}$ is dephased by about 6 months compared to the data, a feature mainly driven by the throughfall $\mathrm{Na}^{+}$input. $\mathrm{Mg}^{2+}, \mathrm{Na}^{+}$and $\mathrm{Ca}^{2+}$ seasonal fluctuations roughly follow measurements at $70 \mathrm{~cm}$ depth (Fig. 10).

Summer and winter weathering profiles differ for the top soil layers (not shown). In winter, all secondary phases dissolve down to $30 \mathrm{~cm}$. Below this depth, precipitation of $\mathrm{Ca}-, \mathrm{K}-$ and $\mathrm{Mg}$-montmorillonites occurs. In summer, all montmorillonites precipitate below $10 \mathrm{~cm}$ except $\mathrm{Na}$ - and $\mathrm{K}$-montmorillonites. Furthermore, weathering rates of secondary minerals (expressed in $\mathrm{kmol} / \mathrm{m}^{2} / \mathrm{s}$ of silicon) are reduced by a factor of 2 in the $0-10 \mathrm{~cm}$ horizon in winter, compared to summer. Silicon budget down to $150 \mathrm{~cm}$ depth is largely controlled by the interaction between secondary phases and soil solution (Figs. 9C and D). For the deep layer (layer 7, 1.50-10 m), both primary and secondary mineral dissolutions (mainly biotite and albite) 

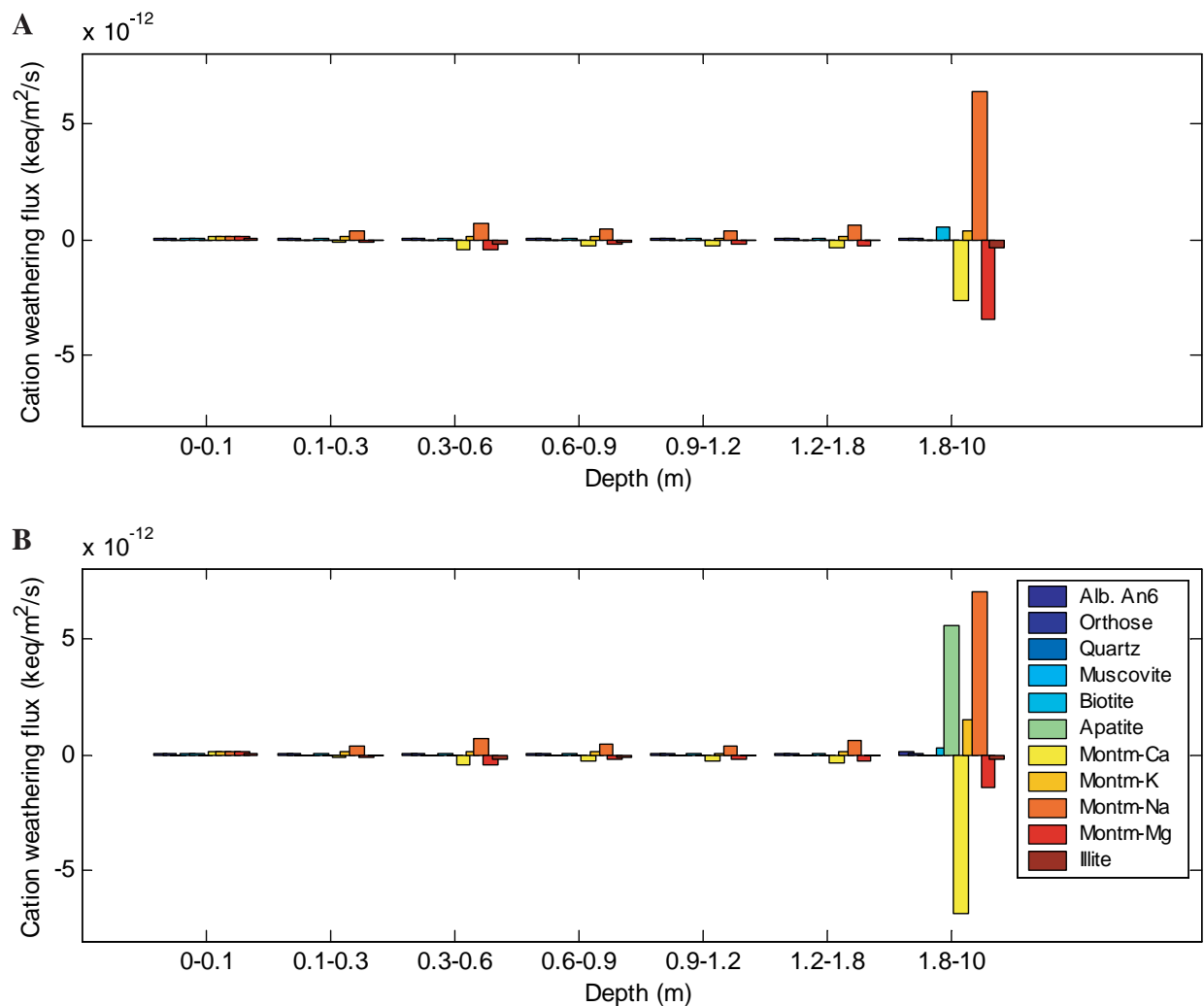

Fig. 8. Calculated base cation flux through weathering or precipitation as a function of the model layer (PP location), and of the minerals, in keq of cations per $\mathrm{m}^{2}$ per second. (A) REF simulation, without apatite, (B) APL10 simulation with apatite only added to the deepest layer at $10 \%$ of the measured abundance in the unaltered rock. All plotted results are for the summer (mean value covering the June-July-August period).

release $\mathrm{Si}$ at depth during summer, resulting in a net release of $13.4 \times 10^{-13} \mathrm{kmol}$ of $\mathrm{Si} / \mathrm{m}^{2} / \mathrm{s}$, while secondary phase precipitation almost balance the Si release by primary mineral dissolution in winter.

\subsection{Calculating the chemical composition of the main stream at the spring collector}

The WITCH model appears to be able to simulate the concentration of the main species within the soil horizons down to about $70 \mathrm{~cm}$ depth, a conclusion already reached with the SAFE model for mean annual simulations (Sverdrup and Warfinge, 1995; Alveteg, 1998; Sverdrup et al., 2002) mainly for Sweden sites. Furthermore, the model also captures first-order seasonal fluctuations for several major species, although discrepancies are sometimes observed. The next challenge now is to check whether the WITCH model can capture the chemical composition of the main stream, through the mixing of the two defined end-members (HP and PP locations). The upscaling of a weathering model working at the soil scale to the watershed scale is a perilous operation. One way of proceeding would be to force the WITCH model with a full 3D physical hydrological model. Such model would require far too many boundary conditions unconstrainable by measurements. As a first attempt towards an integrated modelling of weathering processes at the catchment scale using labo- ratory kinetic laws for the dissolution/precipitation of minerals, we choose a quite simple procedure: the results obtained on the PP location are extended to $80 \%$ of the total surface of the catchment (equivalent to the surface covered by spruces), while results obtained for the HP location are extended to the $20 \%$ of the area covered by beeches. This procedure allows to account for the differences in soil weathering processes related to standing vegetation type, since we found that most of the geochemical signature of the percolating waters are controlled by the interactions between soil solutions and secondary minerals. Such interactions are most probably largely dependent on the hydrological behaviour of the soil profile, itself directly related to the standing vegetation type. But this procedure neglects the variability in mineralogical composition of the bedrock inside the area covered by a given vegetation type (see discussion about the $\mathrm{Ca}^{2+}$ budget in Section 7). Furthermore, at this point of the model development, we were not able to account for lateral transfers of water, or for respective influence of particular contributive areas such as the saturated area connected to the stream (Idir et al., 1999) which vary according to hydrological conditions. We assume that the main stream is fed throughout the year with waters percolating down to the deepest layer, then reaching the impermeable bedrock and flowing to the main stream. As a result, concentrations in the main stream $Q_{\text {stream }}$ are calculated as follows: 
A
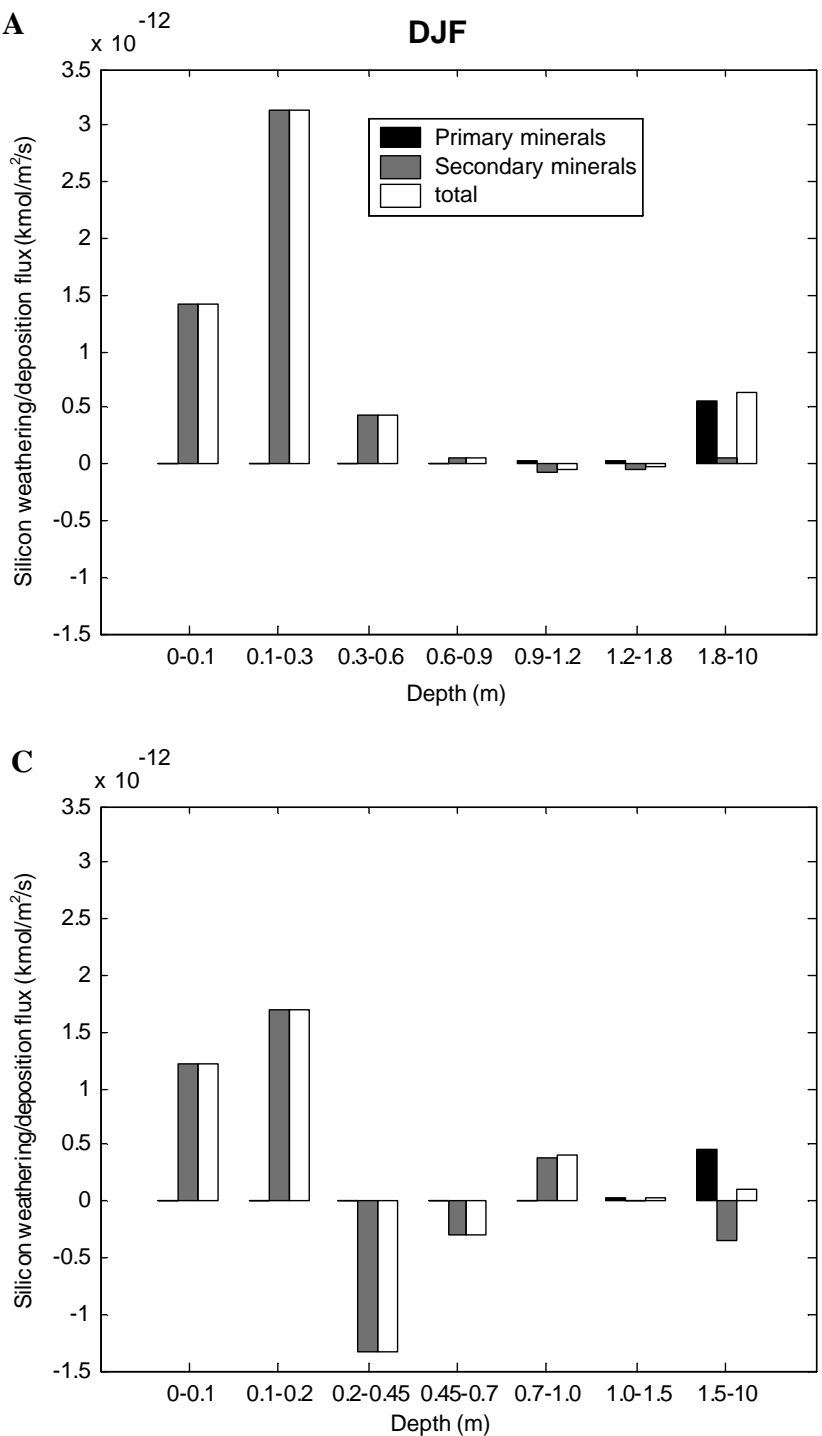

B

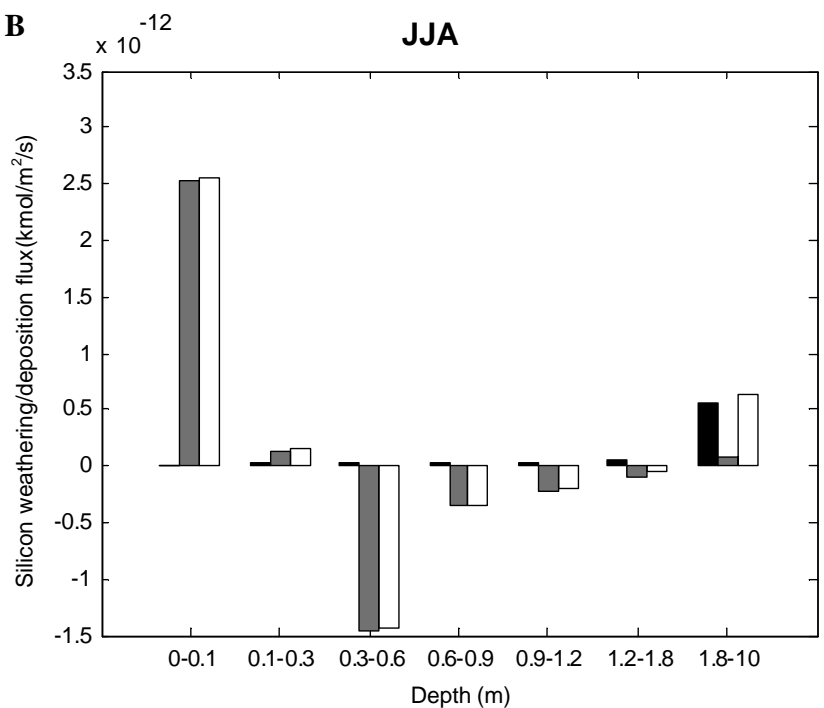

D

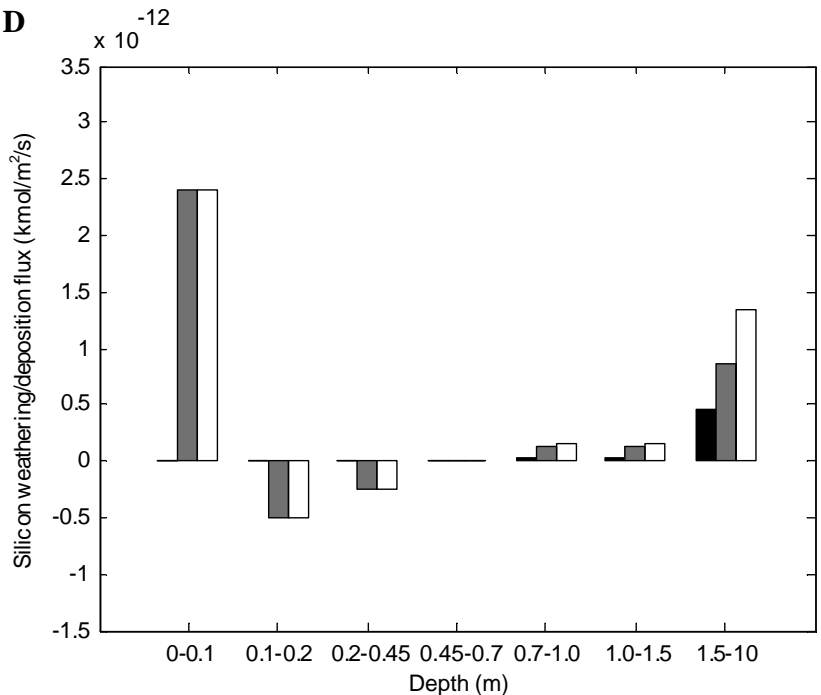

Fig. 9. Simulated exchange of Si between soil solutions and minerals at various depth for the REF simulation. A negative value corresponds to a removal of Si through secondary mineral precipitation, while a positive value stands for an input into the soil solution through a dissolution process. (A) PP location, winter (December-January-February). (B) PP location summer (June-July-August). (C) HP location winter. (D) HP location summer. Note that the scale is not the same from one plot to the other.

$Q_{\text {stream }}=0.80 \cdot Q_{\mathrm{PP}}+0.20 \cdot Q_{\mathrm{HP}}$,

where $Q_{\mathrm{HP}}$ and $Q_{\mathrm{PP}}$ represents, respectively, the concentrations of the various chemical species of interest within layer 7 for the HP and PP locations. This mixing is performed at a seasonal scale, but at this stage, results will be only presented on a mean annual basis since the assumption that all contributing waters are percolating down to the bedrock is justified only at the mean annual scale. All model outputs are now compared to data acquired at the spring collector.

The results yielded by the reference simulation for the spring collector differ significantly from the data. In particular, $\mathrm{Na}^{+}$concentration is overestimated by a factor of 1.7 , while $\mathrm{Ca}^{2+}$ and $\mathrm{Mg}^{2+}$ are underestimated. The biggest discrepancy, however, is observed for $\mathrm{Ca}^{2+}$. The model predicts a mean annual $\mathrm{Ca}^{2+}$ concentration at the spring collector of $13.5 \mu \mathrm{eq} / \mathrm{L}$, compared to the observed
$158 \mu \mathrm{eq} / \mathrm{L}$ (Fig. 11). On the other hand, aqueous silica is accurately predicted by the model $(130 \mu \mathrm{mol} / \mathrm{L}$ calculated vs $140 \mu \mathrm{mol} / \mathrm{L}$ measured).

$\mathrm{Mg}^{2+}$ underestimation can be easily understood considering the integrated silica budget through the soil horizons. Soil solutions become supersaturated with respect to smectite minerals with increased depth (except Na-montmorillonite), resulting in the removal of $\mathrm{Mg}^{2+}$ and silica from the soil solutions during their downward percolation. On the other hand, $\mathrm{Na}^{+}$overestimation results from the dissolution of Na-montmorillonite throughout all horizons in winter and summer. This dissolution of Na-montmorillonite supplies enough aqueous silica, compensating for the removal through $\mathrm{Ca}$ - and $\mathrm{Mg}$-montmorillonite precipitation, explaining why the silica flux is correctly estimated, while the $\mathrm{Mg}^{2+}$ flux is not. 

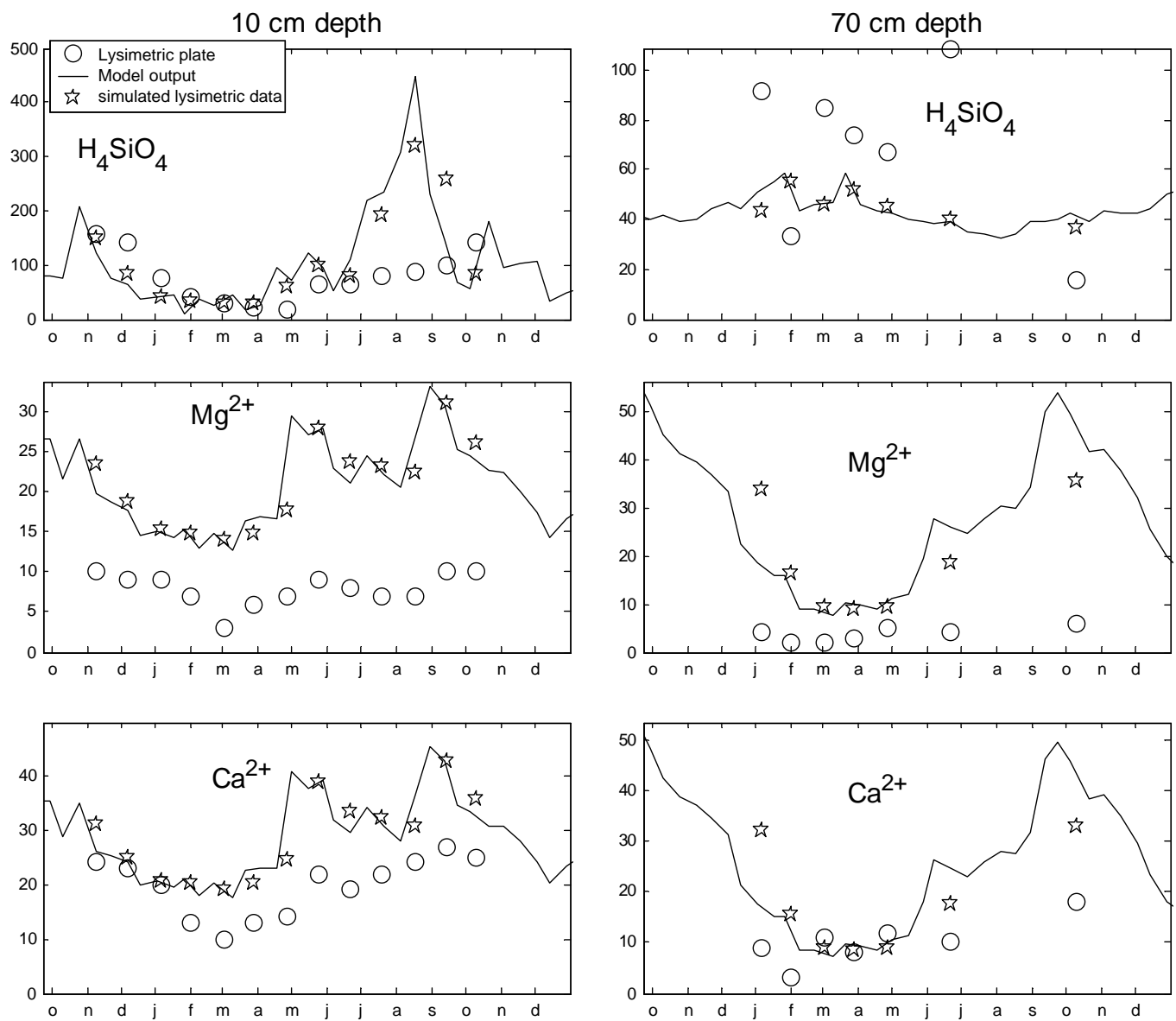

Fig. 10. Simulated $\mathrm{H}_{4} \mathrm{SiO}_{4}, \mathrm{Mg}^{2+}$ and $\mathrm{Ca}^{2+}$ concentration as a function of time for the HP location (REF simulation). Dots stand for data acquired on lysimetric plates, solid line is the model output, and the stars represent the simulated concentrations on lysimetric plates calculated from model output (model output are integrated over the time interval between two lysimetric plate measurements and weighted by the calculated vertical water fluxes).

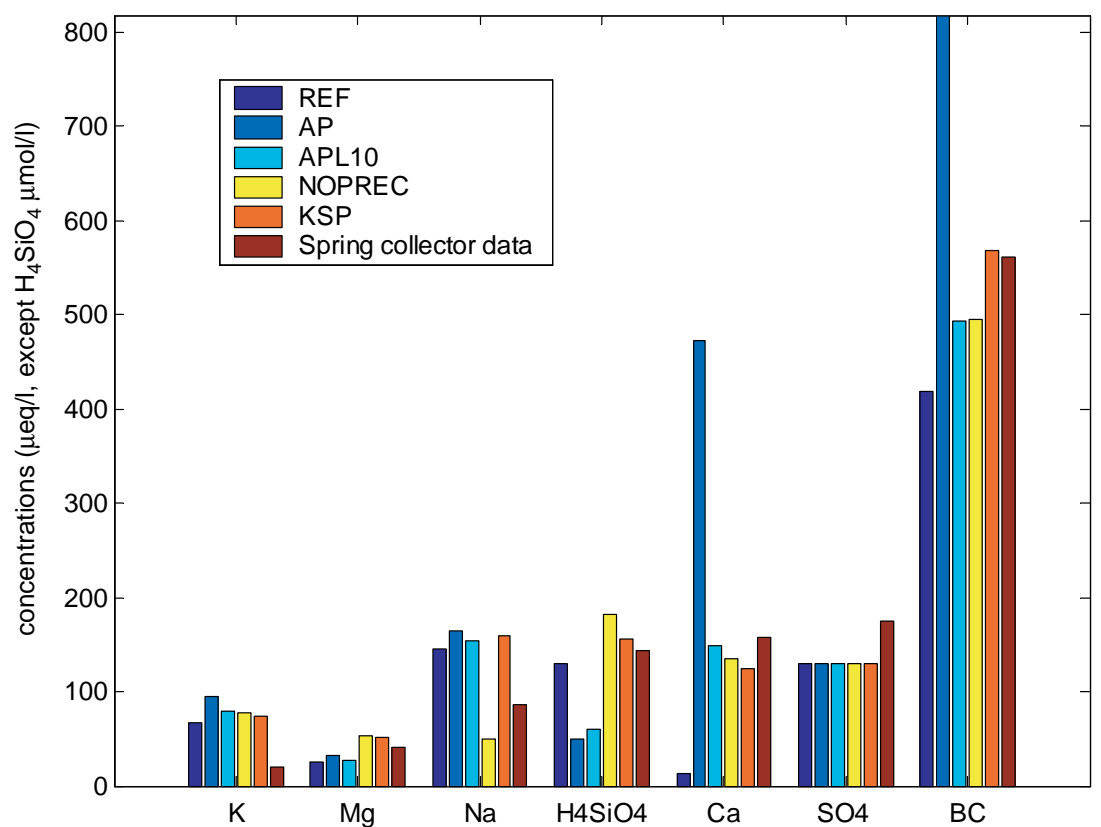

Fig. 11. Mean annual calculated concentrations of major cations, $\mathrm{H}_{4} \mathrm{SiO}_{4}$ and sulphate at the spring collector, compared to spring collector data, and for the reference and sensitivity tests performed (see description in the text). 


\section{AP and APL10 sensitivity tests: Looking for calcium at the spring collector}

The lack of $\mathrm{Ca}^{2+}$ in the calculated chemical composition at the spring collector suggests us a first sensitivity test (AP simulation, Table 4), where apatite is added in each layer as a trace mineral based on the mineralogical composition determined by Fichter et al. (1998a) (for HP: $0.2 \%$ vol of apatite down to $70 \mathrm{~cm}$ depth, $0.3 \%$ vol below; for PP: $0.1 \%$ vol down to $30 \mathrm{~cm}$ depth, 0.3 between 30 and $90 \mathrm{~cm}$ depth, $0.8 \%$ vol below). Results at the spring collector show large changes in the calculated abundance of major elements (Fig. 11), as well as the concentrations of $\mathrm{Ca}^{2+}$ and $\mathrm{SiO}_{2}$ in the soil solutions above $60-70 \mathrm{~cm}$. In soil profiles, $\mathrm{Ca}^{2+}$ increases significantly while $\mathrm{SiO}_{2}$ concentrations falls by a factor of about 2.2 at $60-70 \mathrm{~cm}$ depth (PP profile). $\mathrm{Ca}^{2+}$ increases are driven by the massive release of $\mathrm{Ca}^{2+}$ through apatite dissolution in all layers (peaking at $1 \times 10^{-11} \mathrm{keq} / \mathrm{m}^{2} / \mathrm{s}$ in the top soil horizon in summer, under strongly acidic conditions, compared, for instance, to biotite dissolution reaching a weak $2 \times 10^{-14} \mathrm{keq} / \mathrm{mol} / \mathrm{m}^{2}$ within the same soil horizon). The silica depletion in soil solution is driven by the abundant Ca-montmorillonite precipitation, itself driven by the important $\mathrm{Ca}^{2+}$ concentration increase. The link between the presence of trace apatite and secondary phase precipitation is particularly visible in the deepest model layer: Ca-montmorillonite precipitation removes up to $8 \times 10^{-12} \mathrm{keq} / \mathrm{m}^{2} / \mathrm{s}$ of base cations (mean June-July-August) in the AP simulation, compared to the $2.5 \times 10^{-12} \mathrm{keq} / \mathrm{m}^{2} / \mathrm{s}$ in the REF simulation. The model yields similar results for the HP location.

As a direct consequence of the introduction of trace apatite in the soil horizons, calculated annual mean $\mathrm{Ca}^{2+}$ concentrations at the spring collector reaches $470 \mu \mathrm{eq} / \mathrm{L}$, compared to the measured $158 \mu \mathrm{eq} / \mathrm{L}$ (reference simulation

Table 4

Sensitivity simulations

\begin{tabular}{lll}
\hline & $\begin{array}{l}\text { Apatite } \\
(\% \text { vol in each layer })\end{array}$ & $\begin{array}{l}\text { Secondary } \\
\text { mineral precipitation }\end{array}$ \\
\hline REF & No & Yes \\
& HP: $0-0-0-0-0-0-0$ & \\
& PP: $0-0-0-0-0-0-0$ & \\
AP & Yes in all layers & Yes \\
& HP: $0.2-0.2-0.2-0.2-0.3-0.3-0.3$ & \\
APL10 & PP: $0.1-0.1-0.3-0.3-0.8-0.8-0.8$ & \\
& Yes in deepest layer only & Yes \\
& HP: $0-0-0-0-0-0-0.03$ & \\
NOPREC & PP: $0-0-0-0-0-0-0.08$ & \\
& Yes in deepest layer & No \\
& HP: $0-0-0-0-0-0-0.03$ & \\
KSP & PP: $0-0-0-0-0-0-0.08$ & Yes (montmorillonite \\
& Yes in deepest layer & solubility products \\
& & \\
& HP: $0-0-0-0-0-0-0.03$ & \\
& PP: $0-0-0-0-0-0-0.08$ &
\end{tabular}

yielded $13.5 \mu \mathrm{eq} / \mathrm{L}$, Fig. 11). Furthermore, the enhanced precipitation of $\mathrm{Ca}$-smectites within the soil horizons and in the deepest layer result in a sharp decrease of the calculated $\mathrm{Si}$ concentration at the spring collector ( $\mathrm{Si}$ concentration falls down to $50 \mu \mathrm{mol} / \mathrm{L}$, compared to the observed $140 \mu \mathrm{mol} / \mathrm{L}$ and simulated $130 \mu \mathrm{mol} / \mathrm{L}$ in the reference run).

The presence of apatite within the top soil horizons might be questionable. Apatite dissolution rate is so fast ( 4 orders of magnitude faster than of plagioclase $\left(\mathrm{An}_{6}\right)$ dissolution) that this mineral is not likely to be preserved in highly altered horizons. Indeed, apatite was found in the upper horizons, but mainly as inclusions within much less reactive minerals such as quartz (Fichter et al., 1998b). Hence, in spite of a high solubility, apatite is not available for dissolution in the upper soil layers (El Gh'Mari, 1995; Fichter et al., 1998a; Probst et al., 2000), and its contribution to $\mathrm{Ca}$ budget in surface horizons is suspected to be low (Aubert, 2001).

For that reason, we performed a second sensitivity test (APL10 simulation) assuming the dissolution of apatite only within deep layer 7 , with the abundance estimated by (Fichter et al., 1998a) $(0.8 \%$ in volume for PP, $0.3 \%$ in volume for HP) reduced by a factor of 10 (new abundance of $0.08 \%$ for PP, and $0.03 \%$ for HP). This $10 \%$ factor corresponds to the best fit of the $\mathrm{Ca}^{2+}$ data at the spring collector by the model. The introduction of the $10 \%$ factor can be justified by the fact that bedrock surface in contact with reacting solution is likely to be strongly depleted in apatite because of the very high dissolution rate of this mineral compared to silicate phases. Furthermore, the APL10 simulation yields exactly the same results as the reference simulation for the soil layers down to $150 / 180 \mathrm{~cm}$ depth, where the agreement between data and model results was quite good. The $\mathrm{Ca}^{2+}$ concentration calculated at the spring collector declines from $510 \mu \mathrm{eq} / \mathrm{L}$ (AP simulation) down to $150 \mu \mathrm{eq} / \mathrm{L}$, matching the observed $158 \mu \mathrm{eq} / \mathrm{L}$ (Fig. 11). However, the APL10 simulation does not yield significant increase in calculated aqueous silica concentration compared to the AP simulation. It remains too low compared to the data, suggesting that the extent of well crystallized clay precipitation is overestimated, and mainly amorphous and poorly crystalline phases probably form instead.

\section{NOPREC and KSP simulation: Looking for silica at the spring collector (Table 4)}

The two critical factors when trying to fit the spring collector data appear to be the abundance of apatite within the soil horizons, and the amount of precipitated secondary minerals. The extent of secondary silicate precipitation depends on the solubility products of the crystallizing phases and their precipitation kinetics. Both are important sources of uncertainties, but the computation of true chemical equilibrium with precipitating solids is particularly crucial since available thermodynamic databases only refer to well crystallized clay minerals, and not to poorly crystallized and amorphous silicates that are largely found to precipi- 
tate during low temperature chemical weathering (White and Blum, 1995; Stefansson and Gislason, 2001).

The calculated depletion in silica at the spring collector result from the abundant precipitation of secondary silicates. The NOPREC test was performed by assuming the presence of trace apatite in the deepest layer at $10 \%$ of the fresh rock abundance and by impeding the precipitation of secondary silicates. When supersaturation is reached with respect to kaolinite, montmorillonites or illite, the dissolution and precipitation rates of these secondary minerals are set to zero. It can be seen on Fig. 11 that, for this test, aqueous silica concentration rises at the spring collector, reaching $181 \mu \mathrm{mol} / \mathrm{L}$ (mean annual concentration), slightly above the observed $140 \mu \mathrm{mol} / \mathrm{L} . \mathrm{Mg}^{2+}$ concentration also increases $(54 \mu \mathrm{eq} / \mathrm{L}$ calculated, 40 observed, 26 in APL10 test), while $\mathrm{Na}$ is reduced by a factor $3(50 \mu \mathrm{eq} / \mathrm{L})$.

Preventing precipitation of secondary phases is an extreme test. A last sensitivity test (KSP) was performed by artificially increasing the solubility product of well-crystallized smectites (the dominant secondary phase in the Strengbach catchment in terms of silica budget), to account for the fact that these secondary phases are probably poorly crystallized. As in the APL10 and NOPREC simulations, apatite abundance was fixed at $10 \%$ of the fresh rock abundance in the lowest layer. Several values of the solubility products of smectites were tested and the best fit is obtained when these solubility products are increased by a factor of 8 . Aqueous silica, $\mathrm{Mg}^{2+}$ and $\mathrm{Ca}^{2+}$ concentration all fit the available data at the spring collector, while the results in the soil profile above $70 \mathrm{~cm}$ remains qualitatively unchanged compared to the reference simulations (except for a general slight increase in Si concentration at $60 \mathrm{~cm}$ (PP) and $70 \mathrm{~cm}$ (HP) depth in summer). As a consequence, the total base cation concentration (and hence the atmospheric $\mathrm{CO}_{2}$ consumption through rock weathering once $\mathrm{SO}_{4}{ }^{2-}$ contribution is removed) at the spring collector is correctly predicted by the model $(569 \mu \mathrm{eq} / \mathrm{L}$ compared to the observed $560 \mu \mathrm{eq} / \mathrm{L}$ ).

\section{Trace mineral and base cation budget of a granitic catchment}

The contribution of trace minerals (including epidote, apatite, calcite) to the production of base cations during weathering in various granitic catchments has been investigated through ${ }^{87} \mathrm{Sr} /{ }^{86} \mathrm{Sr}$ measurements of soil solutions and stream waters (Clow et al., 1997; Aubert et al., 2001, 2002; Blum et al., 2002; Oliva et al., 2004; White et al., 2005a). As shown in Table 5, these estimations span a large range of values. For the Strengbach catchment, the WITCH model gives a value of $60 \%$ of base cations released through weathering of trace apatite at the spring collector (KSP simulation, representing the best fit of the spring collector data), a value higher than the $15 \%$ estimated by (Aubert et al., 2001). However, this high calculated value is mainly driven by the contribution from the PP location where apatite contribution to base cation flux reaches $69 \%$. This value reflects the hydrothermally altered mineralogy of the PP site where apatite abundance reaches $0.8 \%$. This mineralogy was extended to $80 \%$ of the watershed area through our upscaling procedure based on vegetation type abundance. For the HP location, the model yields only $26 \%$ of base cation originating from apatite dissolution, a value closer to the (Aubert et al., 2001) estimation, and the HP mineralogy is probably more representative of the mean catchment mineralogy (El Gh'Mari, 1995). On the other hand, ${ }^{87} \mathrm{Sr} /{ }^{86} \mathrm{Sr}$ mixing models may yield large uncertainties, especially when the contribution of apatite is potentially important.

\section{Some uncertainties and limitations}

We deliberately focused on the $\mathrm{Ca}^{2+}, \mathrm{Mg}^{2+}$ and aqueous silica concentration, in our attempt to validate the WITCH model at the spring collector. However, it is worthy to look at the $\mathrm{Na}^{+}$and $\mathrm{K}^{+}$behaviour in the various simulations. Considering the concentrations calculated at the spring collector (Fig. 11), $\mathrm{Na}^{+}$displays a rather conservative behaviour from one simulation to the other (except NOPREC), with a calculated concentration overestimated at about $150 \mu \mathrm{eq} / \mathrm{L}$ compared to the observed $85 \mu \mathrm{eq} / \mathrm{L}$. The main source of $\mathrm{Na}^{+}$within the various layers is the dissolution of Na-montmorillonite that is unstable in all simulations but the NOPREC one. Indeed, $\mathrm{Na}^{+}$concentration falls to $49 \mu \mathrm{eq} / \mathrm{L}$ in the NOPREC simulation. Because precipitation of all secondary phases are inhibited, $\mathrm{pH}$ rises within all layers, and with increasing depth soil solutions become supersaturated with respect to Na-montmorillonite. For instance, $\mathrm{pH}$ rises from 4.86 in the APL10 run (in summer, PP location) to 5.43 in the NOPREC simulation in soil layer 3 (30-60 cm depth), resulting in a strong decrease of $\mathrm{Na}^{+}$ release within the soil layers.

Table 5

Contribution of trace minerals to the total base cation flux exported from the watershed

\begin{tabular}{lll}
\hline & Main stream BC flux (weathering contribution only) (meq/m $\left./ \mathrm{m}^{2} / \mathrm{year}\right)$ & $\begin{array}{l}\text { Percentage of the Ca flux originating from trace mineral } \\
\text { dissolution relative to the total BC flux }\end{array}$ \\
\hline Hubbard Br. & 101 (Drever and Clow, 1995) & $23.5 \%$ (trace apatite) (Blum et al., 2002) \\
Estibère & 167 (Oliva et al., 2004) & $80 \%$ (trace silicates) (Oliva et al., 2004) \\
Loch Vale & 42 (Mast et al., 1990) & $41 \%$ (trace calcite) (Clow et al., 1997; White et al., 1999) \\
Strengbach & Measured: 281 & $15 \%$ (trace apatite) (Aubert et al., 2001) \\
& KSP simulation (spring collector): 285 & $26 \%$ (HP) to 69\% (PP) (trace apatite) (This study) \\
\hline
\end{tabular}


$\mathrm{K}^{+}$is not sensitive to the inhibition of secondary phases precipitation and stabilizes around $70 \mu \mathrm{eq} / \mathrm{L}$ in all simulations (Fig. 11), a value close to the mean $62 \mu \mathrm{eq} / \mathrm{L}$ measured in throughfall, which was used as the input of $\mathrm{K}^{+}$ at the surface. The overestimation of $\mathrm{K}^{+}$concentration at the spring collector is most probably linked to an underestimation of the cycling of $\mathrm{K}^{+}$within the top soil layers. Potassium is extremely sensitive to the biological activity in soils (White et al., 2005b). In this study, the uptake of $\mathrm{K}^{+}$by standing vegetation is calculated from the uptake of carbon in each soil layers by the ASPECTS model, a process that extends down to $0.9 \mathrm{~m}$ depth. It is possible that $\mathrm{K}^{+}$uptake occurs mainly at a shallower depth, preventing this cation from percolating down to the bedrock and to concentrate in the spring collector.

Another possible source of error comes from the assumption that the four types of montmorillonite (Ca-, $\mathrm{Na}-, \mathrm{K}-$ and $\mathrm{Mg}-$ ) are equally abundant in each soil layers. This assumption was made since only the total abundance of smectites was measured. For instance, assuming the absence of Mg-montmorillonite within the smectite pole leads to a 3.5 times decrease in the calculated $\mathrm{Mg}^{2+}$ concentration at the spring collector. Aqueous silica, $\mathrm{Na}^{+}$and $\mathrm{K}^{+}$remain almost unchanged, but $\mathrm{Ca}^{2+}$ concentration is multiplied by 1.5 .

We also test the impact of changing illite solubility product on the cation and aqueous silica concentrations at the spring collector. Decreasing by a factor of 10 this solubility product does not significantly modify the results at the spring collector. Smectites are clearly the dominant secondary phases in terms of dissolved load of the waters.

Thermodynamic data selection appears critical since precipitation of secondary silicate phases exerts a major control on cation and $\mathrm{SiO}_{2}$ export at the watershed scale. Available thermodynamic databases are not fully compatible and coherent. In this work, we took a special care at calculating the solubility product of minerals from the most coherent and robust values for the $\Delta G_{\mathrm{f}}^{0}$ of reacting aqueous species and solids. Similar efforts were devoted to the calculation of the enthalpies of mineral dissolution reaction $\Delta H_{\mathrm{r}}^{0}$ from the $\Delta H_{\mathrm{f}}^{0}$ of reacting species. Despite this special care, significant uncertainties affect the thermodynamic properties of clay minerals, particularly smectites, which control the precipitation of secondary phases. In this study, the Gibbs free energies of all montmorillonites were taken from the most recent SUPCRT values (file speq03. dat). $\Delta G_{\mathrm{f}}^{0}$ values listed in SUPCRT refer to idealized montmorillonites and have been estimated using the "linear approach" of Tardy and Garrels (1974) that assumes that the Gibbs energy of a sheet silicate is the sum of the Gibbs energies of a collection of "silicated" oxide and hydroxide components. Regarding aqueous species, the main uncertainties and controversies affect aluminium and aqueous silica. Thermodynamic properties of $\mathrm{Al}^{3+}$ and $\mathrm{Al}$ hydrolised species were taken from Wesolowski and Palmer (1994) and Castet et al. (1993) which are in good agreement and have been demonstrated to be the most reliable (Tagirov and Schott, 2001). Accordingly, $\log K$ values for all Al-bearing minerals were calculated using these data. For aqueous silica, calculations were performed using the value determined by Walther and Hegelson (1977). However, a new value has been recently proposed by Rimstidt (1997) and incorporated in SUPCRT that is $350 \mathrm{cal} / \mathrm{mol}$ more negative than the former value $\left(\Delta G_{\mathrm{f}_{(29.15)}}^{0}=-199.54 \mathrm{kcal} / \mathrm{mol}\right)$. This revised free energy of $\mathrm{SiO}_{2}(\mathrm{aq})$ yields a significant increase of the solubility product of silicate phases. For example, the solubility product of montmorillonites at $25^{\circ} \mathrm{C}$ is increased by about one order of magnitude. The impact of this new value on calculated results was tested by performing again the APL10 simulation that assumes the dissolution of apatite only within deep layer 7 , with a volumetric abundance ten times below the fresh rock measured abundance. The model predicts correct $\mathrm{Ca}^{2+}$ and $\mathrm{Mg}^{2+}$ concentrations at the spring collector (not shown), but aqueous silica concentration remains underestimated (calculated concentration at $90 \mu \mathrm{mol} / \mathrm{L}$ ). Once again, the same discussion about precipitation of well crystallized phases apply, and the solubility products of montmorillonite must be artificially increased to account both for the base cation and aqueous silica concentration at the spring collector, in agreement with the conclusions reach above.

Accurate prediction of secondary minerals precipitation rates is a major challenge due to the paucity of experimental data, unlike for dissolution rates. In this study precipitation rates were described within the framework of the TST by applying the principle of detailed balancing to the overall reaction (Eq. (3)). s, the order of the dependence of precipitation rate on the saturation index, was set equal to unity since it is difficult to predict it a priori. However, simulation tests performed with different $s$ values demonstrated that $s \ll 1$ induced strong solution supersaturations and thus affected calculated concentrations at the collector.

\section{Conclusions}

This contribution was aimed at constructing a numerical model of weathering at the catchment scale: the WITCH model. The model mainly relies on laboratory kinetic laws to describe chemical weathering in the natural environment. For the first time, a weathering model was forced on a seasonal basis with output of a biospheric productivity model to constrain soil $\mathrm{CO}_{2}$ levels, and release/uptake of elements by the vegetation. Furthermore, the model operation was extended from the root zone down to the bedrock (10 $\mathrm{m}$ depth) through the addition of a deep layer with a long residence time ( 8 months) to account for weathering processes at depth. WITCH was used to simulate weathering processes in soil profile and at the catchment scale for the Strengbach (Vosges) small granitic watershed in temperate environment. The simulations yield the following conclusions: 
(1) We first validate the chemical module of the WITCH model for two soil profiles of the Strengbach catchment, and show that the model is able to reproduce the general behaviour of most major species on a mean annual basis down to $70 \mathrm{~cm}$ depth in the soil, and without considering the presence of any trace minerals. As previously stated (Sverdrup et al., 2002), kinetic laws are able to describe weathering processes within soil horizons, as long as the inhibiting effect of aqueous species on mineral dissolution and the affinities of involved chemical reactions are taken into account. Furthermore, WITCH is able to roughly reproduce the seasonal fluctuations of $\mathrm{Ca}^{2+}, \mathrm{Mg}^{2+}$ and $\mathrm{Si}$ concentrations in interstitial solutions of Strengbach soils.

(2) The silicon budget is almost totally controlled by precipitation/dissolution of secondary minerals (here montmorillonite) inside the root zone. Dissolution of primary minerals contribute marginally to the silicon and cation budget within the root zone.

(3) When simulating the chemical composition at a spring collector through simple integration of the results obtained at the soil profile scale, WITCH was not able to reproduce the observed $\mathrm{Mg}^{2+}$ and $\mathrm{Ca}^{2+}$ concentrations on annual basis. The calculated depletion in silica and $\mathrm{Mg}^{2+}$ (2-3 times lower than measurements) is linked to an ample precipitation of well crystallized secondary phases (smectites) integrated from the surface down to the bedrock. The most dramatic discrepancy between model result and data affects $\mathrm{Ca}^{2+}$ concentrations (underestimated by a factor of 10). This last result suggests a peculiar origin for $\mathrm{Ca}^{2+}$ at the spring collector and in the main stream.

(4) Adding (in agreement with reported bedrock and soil mineralogical composition) trace apatite within the various soil horizon and in the deep box yields a tremendous increase in calculated $\mathrm{Ca}^{2+}$ concentration at the spring collector, with a subsequent removal of aqueous $\mathrm{SiO}_{2}$ through precipitation of secondary minerals triggered by the massive release of $\mathrm{Ca}^{2+}$ within all model layers. This leads to a strong decrease in the concentration of aqueous silica at the spring collector ( $50 \mu \mathrm{mol} / \mathrm{L}$ compared to the measured $140 \mu \mathrm{mol} / \mathrm{L}$ ). The model yields thus only $35 \%$ of the observed $\mathrm{Si}$ concentration at the spring. Assuming the presence of trace apatite only in the deepest layer (below $1.50 \mathrm{~m}$ ) with an abundance ten times below the observed abundance in fresh granitic rocks allows the calculation of a $\mathrm{Ca}^{2+}$ concentration at the spring collector in agreement with available data. However, a strong deficit in aqueous silica is still calculated. Preventing precipitation of well crystallized clay minerals erases the deficit in aqueous silica, suggesting that poorly crystallized, amorphous phases should be included into weathering models. As an illustration, increasing the solubility product of all smectites by a factor of 8 yields an accurate prediction of $\mathrm{Mg}^{2+}, \mathrm{Si}$ and $\mathrm{Ca}^{2+}$ concentrations at the spring collector.

(5) Rigorous modeling of secondary mineral precipitation is essential to decipher the main sources and mechanisms controlling the release of chemical species, to predict their fluxes and thus subsequent atmospheric $\mathrm{CO}_{2}$ consumption. This requires not only reliable data on the rate of precipitation of clay minerals but also knowledge of the solubility products of the poorly crystalline solid phases likely to form in soils. Moreover, approximation of nucleation rates would be necessary for predicting the precipitation of minerals not present in the soil.

\section{Acknowledgments}

Mattias Alveteg and Harald Sverdrup at Lund University are greatly acknowledged for helpful discussions, and help in the computing of exchange processes. A. Clement and B. Fritz at the CGS in Strasbourg helped us with valuable advices when this project was settled. We thank Jean Riotte, Bernard Dupré, Gilles Berger, Oleg Pokrovsky, Eric Oelkers, Jean-Louis Dandurand at LMTG for fruitful discussions. Tom Wolery at Lawrence Livermore Lab is thanked for providing the last SUPCRT versions and for invaluable informations on the origin of montmorillonite thermodynamic data listed in SUPCRT databank. PRAKSYS is acknowledged for the maintenance of the cluster of PC at LMTG, on which simulations have been performed. L.M. François is Research Associate at the Belgian National Foundation for Scientific Research (FRNS). The EGIDE/TOURNESOL program partly financed this work. Tim Drever, Harald Sverdrup and an anonymous reviewer are greatly acknowledged for their careful and constructive reviews, that contribute to improve the original manuscript.

Associate editor: Dimitri A. Sverjensky

\section{References}

Alveteg, M., 1998. Dynamics of forest soil chemistry. Ph.D, Lund University.

Amiotte-Suchet, P., Probst, J.L., Ludwig, W., 2003. World wide distribution of continental rock lithology: implications for atmospheric/soil $\mathrm{CO}_{2}$ uptake by continental weathering and alkalinity river transport to the oceans. Global Biogeochem. Cycles 17 (2).

Aubert, D., 2001. Contribution de l'altération et des apports atmosphériques aux transferts de matières en milieu silicaté: traçage par le strontium et le terres rares. Cas du bassin versant du Strengbach (Vosges, France). Ph.D, Université Louis Pasteur.

Aubert, D., Probst, A., Stille, P., Viville, D., 2002. Evidence of hydrological control of $\mathrm{Sr}$ behavior in stream water (Strengbach catchment, Vosges mountains, France). App. Geochem. 17, 285-300.

Aubert, D., Stille, P., Probst, A., 2001. REE fractionation during granite weathering and removal by waters and suspended loads: $\mathrm{Sr}$ and $\mathrm{Nd}$ isotopic evidence. Geochim. Cosmochim. Acta 65, 387-406. 
Aumont, O., Orr, J.C., Monfray, P., Ludwig, W., Amiotte-Suchet, P., Probst, J.L., 2001. Riverine-driven interhemispheric transport of carbon. Global Biogeochem. Cycles 15 (2), 393-405.

Berner, R.A., Kothavala, Z., 2001. GEOCARB III: a revised model of atmospheric $\mathrm{CO}_{2}$ over Phanerozoic time. Am. J. Sci. 301, 182-204.

Blum, A.E., Stillings, L.L., 1995. Feldspar dissolution kinetics. In: White, A.F., Brantley, S.L. (Eds.), Chemical Weathering Rates of Silicate Minerals, Reviews in Mineralogy, Vol. 31, pp. 291-351.

Blum, J.D., Klaue, A., Nezat, C.A., Driscoll, C.T., Johnson, C.E., Siccama, T.G., Eagar, C., Fahey, T.J., Likens, G.E., 2002. Micorrhizal weathering of apatite as an important calcium source in base-poor forest ecosystems. Nature 417, 729-731.

Bonhomme, M., 1967. Ages radiométriques de quelques granites des Vosges moyennes. Bull. Carte géol. Als. Lorr. 20, 101-106.

Brady, P.V., Carroll, S.A., 1994. Direct effects of $\mathrm{CO}_{2}$ and temperature on silicate weathering: possible implications for climate control. Geochim. Cosmochim. Acta 58 (8), 1853-1856.

Castet, S., Dandurand, J.-L., Schott, J., Gout, R., 1993. Boehmite solubility and aqueous aluminum speciation in hydrothermal solutions $\left(90-350^{\circ} \mathrm{C}\right)$ : experimental study and modeling. Geochim. Cosmochim. Acta 57, 4869-4884.

Chaïrat, C., 2005. Etude expérimentale de la cinétique et des mécanismes d'altération de minéraux apatitiques: Application au comportement d'une céramique de confinement d'actinides mineurs. Ph.D thesis, Université Paul Sabatier, Toulouse.

Clow, D.W., Mast, M.A., Bullen, T.D., Turk, J.T., 1997. 87Sr/86Sr as a tracer of mineral weathering reactions and calcium sources in an alpine/subalpine watershed, Loch Vale, Colorado. Water Resour. Res. 33, 1335-1351.

Dambrine, E., Sverdrup, H., Warfinge, P., 1995. Atmospheric deposition, forest management and soil nutrient availability: a modelling exercise. In: Landmann, G., Bonneau, M. (Eds.), Forest decline and atmospheric deposition effects in the French mountains. Springer-Verlag, New York.

De Pury, D.G.G., Farquhar, G.D., 1997. Simple scaling of photosynthesis from leaves to canopies without errors of big-leaf model. Plant, Cell Environ. 20, 537-557.

Dessert, C., Dupré, B., François, L.M., Schott, J., Gaillardet, J., Chakrapani, G.J., Bajpai, S., 2001. Erosion of Deccan Traps determined by river geochemistry: impact on the global climate and the ${ }^{87} \mathrm{Sr} /{ }^{86} \mathrm{Sr}$ ratio of seawater. Earth Planet. Sci. Lett. 188 (3/4), 459-474.

Dessert, C., Dupré, B., Gaillardet, J., François, L.M., Allègre, C.J., 2003. Basalt weathering laws and the impact of basalt weathering on the global carbon cycle. Chem. Geol. 202, 257-273.

Devidal, J.L., Schott, J., Dandurand, J.-L., 1997. An experimental study of kaolinite dissolution and precipitation kinetics as a function of chemical affinity and solution composition at $150^{\circ} \mathrm{C}, 40$ bars, and $\mathrm{pH}$ 2, 6.8, and 7.8. Geochim. Cosmochim. Acta 61, 5165-5186.

Donnadieu, Y., Goddéris, Y., Ramstein, G., Nédelec, A., Meert, J.G., 2004. Snowball Earth triggered by continental break-up through changes in runoff. Nature 428, 303-306.

Dove, P.M., 1994. The dissolution kinetics of quartz in sodium chloride solutions at $25^{\circ}$ to $300^{\circ}$. Am. J. Sci. 294, 665-712.

Drever, J.I., 1997. The Geochemistry of Natural Waters. Prentice Hall, Upper Saddle River, New Jersey 07458.

Drever, J.I., Clow, D.W., 1995. Weathering rates in catchments. In: White, A.F., Brantley, S.L. (Eds.), Chemical Weathering Rates of Silicate minerals, Vol. 31. Mineralogical Society of America, Washington, D.C., USA, pp. 463-483.

El Gh'Mari, A., 1995. Etude minéralogique, pétrophysique et géochimique de la dynamique d'altération d'un granite soumis aux dépôts atmosphériques acides (bassin versant du Strengbach, Vosges, France): mécanismes, bilans et modélisations, Université Louis Pasteur.

Eyring, H., 1935. The activated complex in chemical reactions. J. Chem. Phys. 3, 107-115.

Fang, C., Moncrieff, J.B., 1999. A model for soil $\mathrm{CO}_{2}$ production and transport 1: Model development. Agri. For. Meteorol. 95, 225-236.

Fichter, J., 1997. Minéralogie quantitative et flux d'éléments minéraux libéré par altération des minéraux des sols dans deux écosystèmes sur granite (bassin versant du Strengbach, Vosges). Ph.D, Université Henri Poincaré, INRA.

Fichter, J., Dambrine, D., Turpault, M.-P., Ranger, J., 1998a. Base cation supply in spruce and beech ecosystems of the Strengbach catchment (Vosges mountains, N-E France). Water Air Soil Poll. 104, 125-148.

Fichter, J., Turpault, M.-P., Dambrine, D., Ranger, J., 1998b. Localization of base cations in particle size fractions of acid forest soils (Vosges Mountains, N-E France). Geoderma 82, 295-314.

Gautier, J.-H., Oelkers, E.H., Schott, J., 2001. Are quartz dissolution rates proportional to B.E.T. surface area? Geochim. Cosmochim. Acta 65, 1059-1070.

Goddéris, Y., François, L.M., 1995. The Cenozoic evolution of the strontium and carbon cycles: relative importance of continental erosion and mantle exchanges. Chem. Geol. 126, 169-190.

Goddéris, Y., Joachimski, M.M., 2004. Global change in the late Devonian: modelling the Frasnian-Famennian short-term carbon isotope excursions. Palaeogeogr. Palaeoclimatol. Palaeoecol. 202, 309-329.

Golubev, S., Pokrovsky, O.S., Schott, J., 2005. Effect of dissolved $\mathrm{CO}_{2}$ on the dissolution kinetics of basic silicates at $25^{\circ} \mathrm{C}$. Chem. Geol. 217, 227-238.

Guidry, M.W., Mackenzie, F.T., 2003. Experimental study of igneous and sedimentary apatite dissolution: control of $\mathrm{pH}$, distance from equilibrium, and temperature on dissolution rates. Geochim. Cosmochim. Acta 67, 2949-2963.

Hodson, M.E., Langan, S.J., Meriau, S., 1998. Determination of mineral surface area in relation to the calculation of weathering rates. Geoderma 83, 35-54.

Holmqvist, J., 2001. Modelling chemical weathering in different scales. Ph.D. thesis, Lund University, Lund.

Idir, S., Probst, A., Viville, D., Probst, J.L., 1999. Contribution des surfaces saturées et des versants aux flux d'eau et d'éléments exportés en période de crue: traçage à l'aide du carbone organique dissous et de la silice. Cas du petit bassin versant du Strengbach (Vosges, France). C.R. Acad. Sci. Paris 328, pp. 89-96.

Köhler, S.J., Dufaud, F., Oelkers, E.H., 2003. An experimental study of illite dissolution kinetics as a function of $\mathrm{pH}$ from 1.4 to 12.4 and temperature from 5 to $50^{\circ} \mathrm{C}$. Geochim. Cosmochim. Acta 67 (19), 3583-3594.

Kump, L.R., Arthur, M.A., 1997. Global chemical erosion during the Cenozoic: weatherability balances the budget. In: Ruddiman, W.F. (Ed.), Tectonic and climate change. Plenum Press, New York, pp. 399 426.

Kump, L.R., Brantley, S.L., Arthur, M.A., 2000. Chemical weathering, Atmospheric $\mathrm{CO}_{2}$, and Climate. Annu. Rev. Earth Planet. Sci. 28, 611667.

Leuning, R., 1995. A critical appraisal of a combined stomatal-photosynthesis model for C3 plants. Plant, Cell and Environment 18, 335 339.

Madé, B., Clément, A., Fritz, B., 1994. Modeling mineral/solution interactions: the thermodynamic and kinetic code KINDISP. Computers and Geosciences 20 (9), 1347-1363.

Mahfouf, J.F., Noilhan, J., 1991. Comparative study of various formulations of evaporation from bare soil using in situ data. J. Appl. Meteorol. 30, 1354-1365.

Mast, M.A., Drever, J.I., Barron, J., 1990. Chemical weathering in the Loch Vale watershed, Rocky mountains National Park, Colorado. Water Resour. Res. 26, 2971-2978.

Munhoven, G., 2002. Glacial-interglacial changes of continental weathering: estimates of the related $\mathrm{CO}_{2}$ and $\mathrm{HCO} 3$ flux variations and their uncertainties. Global Planet. Change 33, 155-176.

Nagy, K.L., 1995. Dissolution and precipitation kinetics of sheet silicates. In: White, A.F., Brantley, S.L. (Eds.), Chemical Weathering Rates of Silicate Minerals, Reviews in Mineralogy, Vol. 31. Mineralogical Society of America, Washington, D.C., USA, pp. 173-233.

Oelkers, E.H., Schott, J., Devidal, J.L., 1994. The effect of aluminum, pH and chemical affinity on the rates of aluminosilicate dissolution reactions. Geochim. Cosmochim. Acta 58, 2011-2024. 
Oliva, P., Dupré, B., Martin, F., Viers, J., 2004. The role of trace minerals in chemical weathering in a high-elevation granitic watershed (Estibère, France): chemical and mineralogical evidence. Geochim. Cosmochim. Acta 68 (10), 2223-2244.

Oliva, P., Viers, J., Dupré, B., 2003. Chemical weathering in granitic crystalline environments. Chem. Geol. 202, 225-256.

Posch, M., Hettelingh, J.-P., Slootweg, J., 2003. Manual for dynamic modelling of soil response to atmospheric deposition, Rijksinstituut voor Volksgezondheid en Milieu, pp. 46-47.

Probst, A., Dambrine, D., Viville, D., Fritz, B., 1990. Influence of acid atmospheric inputs on surface water chemistry and mineral fluxes in a declining spruce stand within a small granitic catchment (Vosges massif, France). J. Hydrol. 116, 101-124.

Probst, A., El Gh'Mari, A., Aubert, D., Fritz, B., McNutt, R., 2000. Strontium as a tracer of weathering processes in a silicate catchment polluted by acid atmospheric inputs, Strengbach, France. Chem. Geol. 170, 203-219.

Probst, A., Fritz, B., Viville, D., 1995. Mid-term trends in acid precipitations, streamwater chemistry and element budgets in the Strengbach catchment (Vosges mountains, France). Water Air Soil Poll. 79, 39-59.

Probst A., Viville D., 1997. Bilan hydrogéochimique du petit bassin versant forestier du Strengbach à Aubure (Haut Rhin). In Rapport scientifique activités de recherche, $5^{\text {ème }}$ réunion du conseil de direction scientifique IfarelDFIU, Conseil de l'Europe, pp. 59-66.

Rasse, D.P., François, L.M., Aubinet, M., Kowalski, A.S., Vande Walle, I., Laitat, E., Gérard, J.C., 2001. Modelling short-term $\mathrm{CO}_{2}$ fluxes and long-term tree growth in temperate forests with ASPECTS. Ecol. Modell. 141, 35-52.

Rimstidt, J.D., 1997. Quartz solubility at low temperatures. Geochim. Cosmochim. Acta 61, 2553-2558.

Schott, J., Oelkers, E.H., 1995. Experimental study of anorthite dissolution and the relative mechanism of feldspar hydrolysis. Geochim. Cosmochim. Acta 59, 5039-5053.

Stefansson, A., Gislason, S.R., 2001. Chemical weathering of basalts, southwest Iceland: effect rock crystallinity and secondary minerals on chemical fluxes to the ocean. Am. J. Sci. 301, 513-556.

Sverdrup, H., Hagen-Thorn, A., Holmqvist, J., Wallman, P., Warfinge, P., Walse, C., Alveteg, M., 2002. Biogeochemical processes and mechanisms. In: Sverdrup, H., Stjernquist, I. (Eds.), Developing Principles and Models for Sustainable Forestry in Sweden. Kluwer Academic Publishers, Dordrecht, pp. 91-196.

Sverdrup, H., Warfinge, P., 1995. Estimating field weathering rates using laboratory kinetics. Rev. Mineral. 31, 485-541.
Tagirov, B., Schott, J., 2001. Aluminum speciation in crustal fluids revisited. Geochim. Cosmochim. Acta 65, 3965-3992.

Tardy, Y., Garrels, R.M., 1974. A method of estimating the Gibbs energies of formation of layer silicates. Geochim. Cosmochim. Acta 38, $1101-1116$

Vieillard, P., 2000. A new method for the prediction of Gibbs free energies of formation of hydrated clay minerals based on the electronegativity scale. Clays Clay Miner. 48, 459-473.

Viterbo, P., Beljaars, C.M., 1995. An improved land surface parametrization scheme in the ECHWF model and its validation. J. Clim. 8, 2716-2748

Walker, J.C.G., Hays, P.B., Kasting, J.F., 1981. A negative feedback mechanism for the long-term stabilization of Earth's surface temperature. J. Geophys. Res. 86, 9776-9782.

Wallman, P., Svensson, M.G.E., Sverdrup, H., Belyazid, S., 2005. ForSAFE-an integrated process-oriented forest model for long term sustainability assessments. Forest Ecol. Manag. 207, 19-36.

Wallman, P., Sverdrup, H., Svensson, M.G.E., Alveteg, M., 2002. Integrated modelling. In: Sverdrup, H., Stjernquist, I. (Eds.), Developing Principles and Models for Sustainable Forestry in Sweden. Kluwer Academic Publisher, Dordrecht, pp. 57-83.

Walther, J.V., Hegelson, H.C., 1977. Calculation of the thermodynamic properties of aqueous silica and the solubility of quartz and its polymorphs at high pressures and temperatures. Am. J. Sci. 277, 13151351.

Warfinge, P., Sverdrup, H., 1998. Soil liming as a measure to mitigate acid runoff. Water Resour. Res. 24, 701-712.

Wesolowski, D.J., Palmer, D.A., 1994. Aluminium speciation and equilibria in aqueous solution: V. Gibbsite solubility at $50{ }^{\circ} \mathrm{C}$ and pH 3-9 in 0.1 molal $\mathrm{NaCl}$ solutions. Geochim. Cosmochim. Acta 58, 2947-2970.

White, A.F., Blum, A.E., 1995. Effects of climate on chemical weathering in watersheds. Geochim. Cosmochim. Acta 59, 1729-1747.

White, A.F., Bullen, T.D., Davison, V.V., Schulz, M.S., Clow, D.W., 1999. The role of disseminated calcite in the chemical weathering of granitoid rocks. Geochim. Cosmochim. Acta 63, 1939-1953.

White, A.F., Schulz, M.S., Lowenstern, J.B., Vivit, D.V., Bullen, T.D., 2005a. The ubiquitous nature of accessory calcite in granitoid rocks: implications for weathering, solute evolution, and petrogenesis. Geochim. Cosmochim. Acta 69 (6), 1455-1471.

White, A.F., Schulz, M.S., Vivit, D.V., Blum, A.E., Stonestrom, D.A., Harden, J.F., 2005b. Chemical weathering rates of a soil chronosequence on granitic alluvium: III. Hydrochemical evolution and contemporary solute fluxes and rates. Geochim. Cosmochim. Acta 69, 1975-1996. 